\title{
MUERTE, RELIGIOSIDAD E IDEOLOGÍA: EL SIGNIFICADO DEL AJUAR EN LOS SEPULCROS DE ALFONSO X Y SANCHO IV DE CASTILLA
}

\author{
POR \\ LEONOR PARRA AGUILAR* \\ Universidad Complutense de Madrid \\ leonorparraaguilar@gmail.com
}

\begin{abstract}
RESUMEN
Los enterramientos de los monarcas del reino de Castilla nos muestran como los reyes pretendían dejar señales de su poder aún en la muerte. A través del estudio detallado y la comparación de los ajuares de Alfonso X y Sancho IV de Castilla, plantearemos una hipótesis que advierte la existencia de un mismo modelo ideológico en ambos monarcas. Para llegar a ello, se prestará atención a los elementos de poder con los que se entierran, que pretenden ser símbolos de la ideología regia. Se verá cómo en los ámbitos funerarios de los poderosos, las pretensiones monárquicas tienden a multiplicar su fortaleza como arma y como propaganda política, siempre apoyándose en la religiosidad para argumentar su poder.
\end{abstract}

PALABRAS CLAVE: Castilla, Alfonso X, Sancho IV, ideología, ajuar, sepulcro, muerte.

\section{DEATH, RELIGIOSITY AND IDEOLOGY: THE MEANING OF THE FUNERARY OBJECTS IN THE TOMBS OF ALFONSO X AND SANCHO IV OF CASTILE}

\begin{abstract}
The burials of monarchs of the kingdom of Castile show us how the kings expected to leave signs of their power even in death. Through careful study and comparison of funerary objects of Alfonso X and Sancho IV of Castile, we will raise a hypothesis, which confirms the existence of the same ideological model in both monarchs. To achieve this, will pay attention to the elements of power with that they demand to entomb themselves that are intended to be symbols of royal ideology. It will be seen how in the funerary areas of the powerful, the monarchical aspirations tend to increase his fortitude as a weapon and as political propaganda, always relying on religiosity for argue their power.
\end{abstract}

KEY WORDS: Castile, Alfonso X, Sancho IV, ideology, funerary objects, sepulchre, death.

Recibido/Received 22-01-2016

Aceptado/Accepted 06-03-2016

\section{INTRODUCCIÓN}

Las sepulturas de los reyes de Castilla y León nos muestran cómo los monarcas extendían su poder aún en la muerte. Con la apertura de los sepulcros de Alfonso $\mathrm{X}$ el Sabio y Sancho IV el Bravo, hemos obtenido una serie de datos sobre el ajuar utilizado que nos permiten tratarlo en profundidad y como conjunto.

El objetivo de este trabajo es el estudio detallado de los ajuares de ambos monarcas, buscando en ellos la ideología que pretendieron respaldar en vida, además de otros deseos y temores. La intención es demostrar como en ámbitos funerarios las pretensiones regias tendían a multiplicar

* En memoria de Enrique Rodríguez-Picavea Matilla. A él, por todo, por tanto. su fortaleza a modo de propaganda política, pero también como arma que les permitiera recordar a los de su reino quién tenía ciertos poderes y que estos emanaban de Dios.

EL DEBATE HISTORIOGRÁFICO SOBRE LA IDEOLOGÍA DEL PODER REAL EN CASTILLA

Primeramente, para poder conocer ideología regia en el siglo XIII castellano, analizamos en un estado de la cuestión el debate historiográfico existente. Además, con esto pretendemos poner las bases ideológicas que se van a trabajar a lo largo de este estudio a través de los ajuares reales.

El significado y las implicaciones del hecho de ser un rey iban apoyados en una serie de argumentos ideológicos que estaban destinados a reforzar y legitimar el poder real. Esto resultaba fundamental para sostener la posición de los monarcas en la jerarquía establecida, buscando así una 
posición incuestionable del poder del rey sobre la totalidad del reino. Diversos trabajos se han esforzado en resaltar los aspectos ideológicos en el reino de Castilla bajomedieval, destacando por su relevancia las obras de José Manuel Nieto Soria. En uno de sus títulos principales, ${ }^{1}$ nos muestra cómo se fue definiendo la imagen e ideología del poder real desde el siglo XIII al XVI. Para ello tomará una serie de presupuestos teóricos asociados al poder real como imágenes, ${ }^{2}$ simbología, leyendas, ${ }^{3}$ mitos o propaganda, además del propio comportamiento del rey en sus situaciones cotidianas. Para él, será en el siglo XIII cuando se asiente de forma definitiva la imagen del poder real a través de la sacralización, el teocentrismo, la moral ${ }^{4}$ y la religiosidad política que da lugar a la máxima expresión de la teología política de la realeza. ${ }^{5}$

Por otra parte tenemos a Marta Haro Cortés, que nos muestra en su estudio la imagen del poder regio a través de los compendios de castigos castellanos en el siglo XIII. ${ }^{6}$ Establece que, desde Fernando III a Sancho IV, ${ }^{7}$ se produjo una evolución en el poder que tuvo como resultado su fortalecimiento progresivo. Resalta la idea del rey como jefe supremo del ejército, del aparato legislativo y judicial, del gobierno y de la administración. Su poder divino como vicario de Dios le daba este papel preeminente. Haro Cortés y Nieto Soria coinciden en la misma línea de opinión: el rey debe ejercer un buen gobierno, en beneficio de una comunidad de naturales; ${ }^{8}$ se apoyará en el teocentrismo

\footnotetext{
1 Nieto Soria, J.M. 1988a. Fundamentos ideológicos del poder real en Castilla (siglos XIII-XVI). Madrid: Eudema; Nieto Soria, J.M. 1994. Sancho IV, 1284-1295: 159-164. Palencia: Diputación Provincial de Palencia - La Olmeda.

2 Sobre las imágenes creadas por el rey Bravo, localizamos en este contexto los trabajos de Bizzarri, H.O. 2002. "Del texto a la imagen: representaciones iconográficas de la realeza en un manuscrito de los Castigos del rey don Sancho IV". Incipit, 22: 53-94; y Haro Cortés, M. 2012. "Proyecto iconográfico del códice miniado de los "Castigos de Sancho IV" (BNE, Ms. 3995)", en Antonia Martínez Pérez y Ana Luisa Baquero Escudero (coords.), Estudios de literatura medieval: 25 años de la Asociación Hispánica de Literatura Medieval: 83-104. Murcia: Servicio publicaciones Universidad de Murcia.

3 Nieto Soria, J.M. 1989. "Los fundamentos mítico-legendarios del poder regio en la Castilla bajomedieval", en Jean-Pierre Etienvre (ed.), La leyenda. Antropología, historia, literatura: actas del coloquio celebrado en la Casa de Velázquez, Madrid 10 y 11-XI-1986: 56-68. Madrid: Casa de Velázquez y Universidad Complutense de Madrid.

4 Surge la idea del perfeccionismo del rey ideal, cristianísimo y virtuosísimo.

5 Nieto Soria, J.M. 1986. "Imágenes religiosas del rey y del poder real en la Castilla del siglo XIII". En la España Medieval, 5: 710-729; Nieto Soria, J.M. 1989: 56-68; Nieto Soria, J.M. 1987. “La monarquía Bajomedieval castellana ¿Una realeza sagrada?", en Homenaje al profesor Juan Torres Fontes, vol. II: 1225-1237. Murcia: Universidad de Murcia.

6 Haro Cortés, M. 1996. La imagen del poder real a través de los compendios de castigos castellanos del siglo XIII. Londres: Departament Studies - Queen Mary and Westfield College.

7 En esta línea también: Fournès, G. 2004. “L'idéalité royale en Castille au XIII ${ }^{\mathrm{e}}$ siècle: des Sept Parties aux Castigos del rey don Sancho IV". Cahiers de linguistique et de civilisation hispaniques médiévales, 27: 293-310.

8 En esta línea Estepa Díez, C. 2010. "Naturaleza y poder real en Castilla", en J.A. Jara Fuente, G. Martin, I. Alfonso (coords.), Construir la identidad en la Edad Media: poder y memoria en la Castilla de los siglos VII a XV: 163-182. Cuenca: Ediciones de la Universidad de Castilla-La Mancha, trata el vínculo esencial político de la naturaleza respecto al Rey y al Reino, además de su confluencia con el vasallaje; y Nieto Soria, J.M. 2007. "El poder real como representación en la monarquía castellano-
} leonesa del siglo XIII". Res Publica, 17: 81-104. para su legitimación; debe ser un rey ejemplarizante; tener un comportamiento cívico y ético; y debe transmitir su conocimiento como fuente de saber al Reino. Esto nos muestra que aunque inicialmente el rey Bravo fuera partidario de una ruptura total con casi todos los aspectos relacionados con el reinado de su padre, finalmente recurrió a él como buen instructor que fue del poder regio. ${ }^{9}$

Frente a las tesis desarrolladas por Nieto Soria, nos encontramos con las ideas contrarias de Peter Linehan, ${ }^{10}$ Adeline Rucquoi ${ }^{11}$ y Teófilo F. Ruiz. ${ }^{12}$ En los tres autores hallamos la teoría de que la realeza castellana no necesitaba de ninguna sacralización. Los monarcas no adquirieron carácter sobrenatural o mágico, ya que no se les ponía en tela de juicio. Desarrollan las ideas del rey guerrero como cabeza de la nobleza y protector del pueblo y la Iglesia, ${ }^{13}$ la adopción de una "sabiduría divina" como atributo del rey o la idea del imperium como poder supremo herencia de los antepasados romanos. Sin embargo, no aparecen rituales obligatorios como la unción, la coronación o los poderes milagrosos de curación ya que suponen que la realeza en la España medieval no tiene esos ritos porque no pertenecen al mismo ámbito cultural que Francia o Inglaterra. ${ }^{14}$ En esta línea y respecto a la taumaturgia de Sancho IV, Linehan se pronuncia siendo poco optimista frente a la lucidez de Álvaro Pelayo, el cual aseguró haber sido testigo de un milagro de curación efectuado por el rey Bravo. ${ }^{15}$

\section{EL REFLEJO DEL PODER REGIO EN LA MUERTE DEL REY}

La muerte es uno de los momentos más relevantes de cualquier reinado. No sólo conlleva el dolor humano por la pérdida de un ser amado, también se muestra como propaganda política, religiosa y, en ocasiones, como un arma política. Los enterramientos se convertían en un método para buscar la perfección tan ansiada en vida. Las virtudes y

9 Esto lo podemos observar en Gómez Redondo, F. 1998. Historia de la prosa medieval castellana I: La creación del discurso prosístico: el entramado cortesano: 853-1090. Madrid: Ediciones Cátedra; González Mínguez, C. 2012. Poder real y poder nobiliar en la Corona de Castilla (1252-1369): 61-90. Bilbao: Universidad del País Vasco; Nieto Soria, J.M. 1988a; Nieto Soria, J.M. 1997. “Origen divino, espíritu laico y poder real en la Castilla del siglo XIII". Anuario de Estudios Medievales, 27: 43-101.

10 Linehan, P. 2012. Historia e historiadores de la España Medieval: 487-528. Salamanca: Universidad de Salamanca.

11 Rucquoi, A. 1995. "De los reyes que no son taumaturgos. Los fundamentos de la realeza en España". Temas medievales, 5: 163-186 y reeditado en 2006. Rex, Sapientia, Nobilitas. Estudios sobre la Península Ibérica Medieval: 9-45. Granada: Universidad de Granada.

12 Ruiz, T.F. 1984. "Une royauté sans sacré: la monarchie castillane du bas Moyen Âge". Annales. Économies, Sociétés, Civilisations, 39: 429-453; Ruiz, T.F. 1987. "L'image du pouvoir à travers les sceaux de la monarchie castillane", en Adeline Rucquoi (dir.), Génesis medieval del estado moderno: Castilla y Navarra (1250-1370): 217-227. Valladolid: Ámbito.

13 No podían renunciar a la Iglesia y el poder que ejercía, pero sí podían intentar controlarla (Nieto Soria, J.M. 1997). Es la presión de ésta respecto al poder lo que aumentó la utilización de argumentos jurídicoinstitucionales (Nieto Soria, J.M. 2000. "Religión y política en la Castilla bajomedieval: algunas perspectivas de análisis en torno al poder real". Cuadernos de historia de España, 76: 99-120).

14 Rucquoi, A. 1995.

15 Linehan, P. 2012: 528 
deseos perseguidos por el monarca se plasmaban en el ajuar y el sepulcro, siendo la muerte del rey un lugar con connotaciones inmortalizadoras, que buscaba dibujar un rey perfecto, cristianísimo, virtuosísimo, gran gobernante y guía de su pueblo, lleno de ideales por los que luchar: todo un ejemplo. ${ }^{16}$

Cuando un rey fallecía se seguían unas honras fúnebres acordes al rango del difunto, enterrándose de acuerdo al esplendor y magnificencia atribuidos al ámbito regio. Además se tenían en cuenta tres factores fundamentales: la muerte física que se trataba a través del embalsamamiento y otras técnicas como la extirpación de ciertos órganos; la caída en pecado y la respectiva condena en el Purgatorio, por lo que resultaba fundamental recibir los auxilios espirituales; y la perduración de la memoria, donde el papel de los cronistas era fundamental ya que en sus manos estaba la fama positiva o negativa del monarca fallecido. ${ }^{17}$

En este trabajo, se van a tratar los elementos con los que se enterraba un monarca, ya que esto nos permite ir más allá de la imagen que pretendían darnos los cronistas y nos muestran la ideología y deseos que defendían los reyes. Al fin y al cabo, las ropas e insignias actúan como expresión visible del poder, siendo el conjunto del sepulcro un medio de comunicación en potencia.

Para evaluar el ajuar de Alfonso X y Sancho IV se van a utilizar los argumentos ideológicos aportados en el apartado de este trabajo titulado: "El debate historiográfico sobre la ideología del poder real en Castilla". Por ello, aunque no se citen directamente los autores, se ha de recurrir a las obras ya citadas.

\section{Ajuar de Alfonso $X$}

Cuando nos enfrentamos a la muerte del rey Sabio, tenemos la suerte de contar con diversas pruebas. Para trabajar sobre el momento del fallecimiento en sí, contamos con sus dos últimos testamentos, la Crónica de los Reyes de Castilla de Jofré de Loaysa ${ }^{18}$ y las Crónicas de los reyes de Castilla. ${ }^{19}$ Los testamentos ofrecen documentación interesante que podemos explotar para conocer ciertas cualidades de su enterramiento. Sin embargo, cuando se accede a las crónicas encontramos los actos que se realizaron, pero no se detalla qué se hizo en los mismos. Jofré de Loaysa sólo nos dice que Alfonso $X$ muere en Sevilla, pero no nos da a

16 Un importante trabajo que trata los sepulcros reales en la Península Ibérica en fechas anteriores a las aquí tratadas y que nos pone en antecedentes es el de Dectot, X. 2009. Les tombeaux des familles royales de la Péninsule Ibérique au Moyen Âge. Turnhout: Brepols.

17 Mitre Fernández, E. 1988. "La muerte del rey. La historiografía hispánica (1200-1348) y la muerte entre las élites". En la España medieval, 11: 167-183; Mitre Fernández, E. 1991. "Muerte y memoria del Rey en la Castilla bajomedieval", en La Idea y el sentimiento de la muerte en la historia y en el arte de la Edad Media: 17-26. Santiago de Compostela: Universidad de Santiago de Compostela.

18 Loaysa, Jofré de; Antonio García Martínez (ed.) 1982. Crónica de los Reyes de Castilla, Fernando III, Alfonso X, Sancho IV y Fernando IV (1248-1305). Murcia: Academia Alfonso X el Sabio; Edición, traducción, introducción y notas por Antonio García Martínez.

19 Rossel, C. 1875-1878. Crónicas de los reyes de Castilla, desde Don Alfonso el Sabio hasta los católicos Don Fernando y Doña Isabel: 3 vols. Madrid: M. Rivadeneyra. conocer si sabían de qué fallece, ${ }^{20}$ ni cómo fueron sus funerales. ${ }^{21}$ Por otra parte, en las Crónicas que recopiló Rosell son igualmente concisos. ${ }^{22}$ Sabemos que el rey Sabio sigue una serie de estereotipos, como pedir perdón a sus súbditos por sus errores y a la vez perdonar a los que le hirieron, como sucedió con su hijo Sancho. Asimismo sabemos que comulgó y murió. Posteriormente, los que estaban en Sevilla hicieron muy grand llanto por el. ${ }^{23}$ No se nos da a conocer cuántos días dura el funeral, aunque puede que fueran varios si le enterraron con el nuevo rey presente, ya que Sancho se entera en Ávila de la muerte de su padre y le da tiempo a bajar a Sevilla después de pasar por Toledo y Uclés. Esto despierta otro problema: no sabemos si Sancho estuvo en el entierro de su padre a ciencia cierta. La crónica nos dice que en "el llanto" por Alfonso estaba el infante don Juan, su hija Beatriz -reina de Portugal-, y otros infantes, entre los cuales no sabemos si estaba Sancho.

Respecto al entierro, únicamente se dice que: é despues enterránronlo en Santa Maria de Sevilla, cerca del rey don Fernando, su padre, é de la reina donna Beatriz, su madre. Alfonso X pidió enterrarse en el monasterio de Santa María la Real de Murcia o en Sevilla junto a sus padres, ${ }^{24}$ acabando su cuerpo en la catedral de esta última ciudad. Son numerosos los autores que han tratado la Capilla Real de la primitiva catedral de Sevilla, ${ }^{25}$ por lo este trabajo no pretende volver

20 Cabrera Sánchez, M. 2011. "La muerte de los miembros de la realeza hispánica medieval a través de los testimonios historiográficos". En la España medieval, 34: 106-107.

Además, no se saben con seguridad las causas de su muerte, pero sí conocemos "gracias al estudio forense de Juan Delgado Roig" que padeció un proceso tumoral que maltrató el lado izquierdo de su rostro, algo que el monarca dejó reflejado en algunos textos como las Cantigas: Delgado Roig, J. 1948. "Examen médico legal de unos restos históricos". Archivo hispalense: Revista histórica, literaria y artística, 9/27-32: 151.

21 Loaysa, J.; García Martínez, A. (ed.) 1982: 121.

22 Rossel, C. 1875-1878: Crónica de Alfonso X, capítulo LXXVII.

También se puede acudir a la edición más nueva de la Crónica de Alfonso X: González Jiménez, M. (ed.) 1999. Crónica de Alfonso X. Según el Ms. II/2777 de la Biblioteca del Palacio Real (Madrid). Edición, transcripción y notas. Murcia: Real Academia Alfonso X el Sabio.

${ }_{23}$ Sobre el duelo: Muñoz Fernández, A. 2009. "Llanto, palabras y gestos. La muerte y el duelo en el mundo medieval hispánico (morfología ritual, agencias culturales y controversias)". Cuadernos de historia de España, 83: 107-140.

24 Ballesteros Beretta, A. 1984. Alfonso X el Sabio: 1051-1052. Barcelona: El Albir.

25 Alonso Álvarez, R. 2003. “De Carlomagno al Cid: la memoria de Fernando III en la capilla real de Sevilla", en Fernando III y su tiempo (12011252), VIII Congreso de Estudios Medievales: 469-488. Ávila: Fundación Sánchez-Albornoz; Alonso Álvarez, R. 2007. "Los enterramientos de los reyes de León y Castilla hasta Sancho IV: Continuidad dinástica y memoria regia". E-Spania: Revue électronique d'études hispaniques médiévales, 3; Bango Torviso, I.G. 1992. "El espacio para enterramientos privilegiados en la arquitectura medieval española". Anuario del Departamento de Historia y Teoría del Arte, 4: 93-132; Chamberlin, C.L. 2000. “Unless the pen writes as it should: the proto-cult of Saint Fernando III in Seville in the thirteenth and fourteenth centuries", en Manuel González Jiménez (coord.), Sevilla 1248: Congreso Internacional Conmemorativo del 750 Aniversario de la Conquista de la Ciudad de Sevilla por Fernando III, Rey de Castilla y León, Sevilla, Real Alcázar, 23-27 de noviembre de 1998: 389-418. Madrid: Centro de Estudios Ramón Areces; Cómez Ramos, R. 1979. Las empresas artísticas de Alfonso X el Sabio. Sevilla: Diputación de Sevilla; Fernández Fernández, L. 2010. “"Muy noble, et mucho alto et mucho honrado". La construcción de la imagen de Fernando III», en Carlos de Ayala Martínez, Martín Federico Ríos Saloma (coords.), 
a centrarse en la catedral hispalense, sino completar esos estudios con un análisis detallado del ajuar del rey Sabio.

No se saben con seguridad las causas de su muerte, pero sí conocemos -gracias al estudio forense de Juan Delgado

Fernando III: tiempo de cruzada: 137-164. Madrid-México: Universidad Nacional Autónoma de México, Instituto de Investigaciones Históricas, Sílex; Jiménez Martín, A. 1997. Cartografía de la Montaña Hueca. Notas sobre los planos históricos de la Catedral de Sevilla. Sevilla: Cabildo Metropolitano de la Catedral; Jiménez Martín, A. 2006. "Las fechas de las formas", en Alfonso Jiménez Martín (coord.), La catedral de Sevilla. Fundación y fábrica de la obra nueva: 15-114. Sevilla: Universidad de Sevilla; Laguna Paúl, M.T. 2001. "La capilla de los reyes de la primitiva Catedral de Santa María de Sevilla y las relaciones de la Corona castellana con el cabildo hispalense en su etapa fundacional (1248-1285)", en Isidro G. Bango Torviso (coord.), Maravillas de la España medieval: Tesoro sagrado y monarquía, vol. I: 235-251. Valladolid: ed. Junta de Castilla y León; Laguna Paúl, M.T. 2009a. "El Imperio y la Corona de Castilla: la visita a la capilla de los Reyes de Sevilla en 1500", en María C. Cosmen, María Victoria Herráez Ortega, María Pellón Gómez-Calcerrada (coords.), El intercambio artístico entre los reinos hispanos y las cortes europeas en la Baja Edad Media: 217-238. León: Universidad de León; Laguna Paúl, M.T. 2009b. ""Si el nuestro cuerpo fuere enterrado en Sevilla". Alfonso X y la capilla de los reyes', en Alfonso X el Sabio [exposición] Sala San Esteban, Murcia, 27 octubre 2009-31 enero 2010: 116129. Murcia: Comunidad Autónoma Región de Murcia, Ayuntamiento de Murcia y Caja de Ahorros del Mediterráneo; Laguna Paúl, M.T. 2013a. "Devociones reales e imagen pública en Sevilla". Anales de historia de arte, № Extra 2: 127-157; Laguna Paúl, M.T. 2013b. "Mobiliario medieval de la capilla de los Reyes de la catedral de Sevilla. Aportaciones a los "ornamenta ecclesiae" de su etapa fundacional". Laboratorio de Arte: Revista del Departamento de Historia del Arte, 25, 1: 53-77; Martínez de Aguirre, J. 1995. "La primera escultura funeraria gótica en Sevilla: la Capilla Real y el Sepulcro de Guzmán el Bueno (1248-1320)". Archivo español de arte, Tomo 68, 270: 111-130; Merchán Cornello, M.M. 1958. Historia de la Capilla Real de Sevilla, Tesis de licenciatura dirigida por el profesor Julio González y defendida el 28-02-1958 en la Facultad de Filosofía y Letras de la Universidad de Sevilla. Apéndice documental № 4: 294-303; Nieto Soria, J.M. 2001. “La coronación del rey: los símbolos y la naturaleza de su poder", en Miguel Rodríguez Llopis (coord.), Alfonso $X$ y su época: el siglo del rey sabio: 127-152. Barcelona: Carroggio; Nogales Rincón, D. 2009. La representación religiosa de la monarquía castellano-leonesa: la Capilla Real (1252-1504), Tesis doctoral bajo la dirección de José Manuel Nieto Soria, Universidad Complutense de Madrid, 2009; Nogales Rincón, D. 2014. “Rey, sepulcro y catedral. Patrones ideológicos y creación artística en torno al panteón regio en la corona de Castilla (1230-1516)", en María Dolores Teijeira Pablos, María Victoria Herráez Ortega y María C. Cosmen (coords.), Reyes y prelados: Ia creación artística en los reinos de León y Castilla (1050-1500): 257-282. Madrid: Sílex Ediciones; Pérez Monzón, O. 2012. "Imágenes sagradas. Imágenes sacralizadas. Antropología y devoción en la Baja Edad Media". Hispania sacra, 64/130: 449-495; Rodríguez López, A. 1991. "Fernando III el Santo (1217-1252): evolución historiográfica, canonización y utilización política", en Miscel.lania en homenatge al P. Agustí Altisent: 573 588. Tarragona: Diputación de Tarragona; Roumier, J. 2013. “Un mundo de colores. Fuerza y significado del cromatismo en los relatos de viajes hispánicos a finales de la edad media". Epos: Revista de filología, 29: 117-129; Ruiz Souza, J.C. 1998. "Las capillas reales catedralicias bajomedievales de Sevilla, Toledo y Córdoba", en II Jornadas técnicas de conservadores de las catedrales. Las catedrales de España. Alcalá de Henares, 6-7 Noviembre de 1998, Alcalá de Henares: Universidad de Alcalá de Henares; Ruiz Souza, J.C. 2006. "Capillas Reales funerarias catedralicias de Castilla y León: nuevas hipótesis interpretativas de catedrales de Sevilla, Córdoba y Toledo". Anuario del Departamento de Historia y Teoría del Arte, 18: 9-30; Sánchez Ameijeiras, R. 2002. "La fortuna sevillana del códice florentino de las Cantigas: tumbas, textos e imágenes". Quintana: revista de estudios do Departamento de Historia da Arte, 1: 257-273; Sanz Serrano, M.J. 1998. "Imagen del antiguo tabernáculo de plata, de la Capilla Real de Sevilla, a través de dos sellos medievales", Laboratorio de Arte: Revista del Departamento de Historia del Arte, 11: 51-68.
Roig- ${ }^{26}$ que padeció un proceso tumoral que maltrató el lado izquierdo de su rostro, ${ }^{27}$ algo que el monarca dejó reflejado en algunos textos.

Las diversas aperturas del sepulcro de Alfonso $X$ han sido recogidas por María Jesús Sanz, ${ }^{28}$ que a su vez ha rescatado los datos de otros autores de los siglos XVI al XVIII, ${ }^{29}$ así como otros estudios realizados en el siglo xx por Juan Delgado Roig y Manuel Gómez-Moreno de la que fue la última apertura de su tumba en $1948 .{ }^{30}$ Todos estos estudios han ayudado a hacer un análisis conciso de todo el ajuar del rey Sabio, buscando en él una serie de motivos ideológicos. ${ }^{31}$

Al analizar el ajuar de Alfonso $X$, encontramos que la intención evidente del monarca es enterrarse como el rey, además de presentarse ante nosotros con claras insignias unidas al Imperio, la labor más costosa e infructuosa de su reinado. Su enterramiento se puede interpretar como propaganda política, pero ciertamente vemos que transmite un mensaje nada inocente en el que se sitúa como emperador, aunque nunca lo fue, por lo que resulta un arma política. Lo que nos queda realmente claro al ver su ajuar funerario es que era rey de Castilla y León, un monarca que vestía en dorados y rojos.

Ciertos elementos del ajuar del rey Sabio, se mantuvieron ocultos a los ojos de los observadores estando bajo las ropas principales. Primeramente encontraron un ceñidor realizado en piel y tintado en tonalidades rojizas en la cintura. Servía para sostener las calzas -desaparecidas en la actualidad-y la ropa interior. La primera tela sobre el cuerpo era una camisa de lienzo, que tenía sobre los hombros una tela dorada de función poco reconocible hoy en día. Sobre todo esto se halló una túnica, que llamaremos "interior" ya que sobre ella iría otra de mayor grosor. Esta túnica interior llegaba por debajo de las rodillas y tenía las mangas ajustadas a las muñecas mediante seis botones de plata dorada. Estaba realizada con sedas y con leones y castillos bordados. La túnica exterior es la más relevante ideológicamente por lo que representaban sus imágenes.

Todos los elementos del ajuar de Alfonso $X$ tienen la función de transmitir un mensaje ideológico. Lo más habitual es la utilización recurrente de los emblemas heráldicos,

26 Delgado Roig, J. 1948: 151.

27 Esto también lo trata Presilla, M.E. 1987. "The Image of Death and Political Ideology in the Cantigas de Santa María", en Studies on the "Cantigas de Santa María". Art, Music, and Poetry: 403-457. Madison: Universidad de Nueva York. Concretamente en las páginas: 435-436.

28 Sanz Serrano, M.J. 2000. "Ajuares funerarios de Fernando III, Beatriz de Suabia y Alfonso X", en Manuel González Jiménez (coord.), Sevilla 1248: Congreso Internacional Conmemorativo del 750 Aniversario de la Conquista de la Ciudad de Sevilla por Fernando III, Rey de Castilla y León, Sevilla, Real Alcázar, 23-27 de noviembre de 1998: 419-450. Madrid: Centro de Estudios Ramón Areces.

29 Morgado, A. 1587. Historia de Sevilla, en la qual se contienen sus antigüedades, grandezas, y cosas memorables en ella acontecidas, desde su fundación hasta nuestros tiempos. Libro IV. Sevilla: Imprenta de A. Pescioni y J. de León; Ortiz de Zúñiga, D. 1796. Anales eclesiásticos y seculares de la muy noble y muy leal ciudad de Sevilla metrópoli de Andalucía, tomo IV y V. Madrid: Imprenta Real.

30 Delgado Roig, J. 1948: 135-153 y Gómez-Moreno, M. 1948. "Preseas reales sevillanas". Archivo hispalense: Revista histórica, literaria y artística, 9/27-32: 191-204.

31 Todos los elementos del ajuar que en este trabajo se mencionan son los recogidos por todos estos autores. 
dando gran vistosidad cromática ya que aparecían en casi todas las superficies posibles. ${ }^{32}$ Encontramos, por ejemplo, los guantes y la bolsa que lucía el rey Sabio en su enterramiento, bordados en su totalidad con cuadrículas que emulaban los cuarteles del escudo del reino de Castilla y León. Ambos estaban bordados con seda. Los guantes tenían los dedos abiertos y la bolsa estaba hecha para ir sujeta al cinturón. Ambas prendas parecen realizadas por tejedores castellanos o al menos cristianos, existiendo un gran contraste entre estos bordados y los de influencia mudéjar. ${ }^{33}$

La túnica superior llegaba, al igual que la interior, por debajo de las rodillas. Se encontraba abierta por los costados hasta la cintura, las mangas eran anchas hasta medio brazo y estaba forrada en piel. Toda su superficie estaba decorada con bordados de castillos y leones metidos en círculos, realizados para los castillos en oro y para los leones en plata. El fondo de los círculos de los castillos era carmesí y el de los leones era en plata, imitando al blanco. Todo ello se encontraba rodeado de un fondo malva en el que sobresalían decoraciones vegetales en cuadrícula, las cuales estaban realizadas con hilos de seda en diversos colores. Esta túnica nos recuerda a algunas que ya se han visto en retratos del rey Alfonso X en el Libro de los Juegos, ${ }^{34}$ y que nos ayudan a imaginar -sin asomarnos a su tumba-cómo se hizo enterrar el monarca. La única diferencia que encontramos en la túnica respecto a las retratadas, es que en lo alto de la misma y rompiendo la simetría, se halla un águila al natural de alas extendidas realizada en pardo sobre pajizo. La túnica iba sujeta con un cinturón de piel de cabritilla teñida en rojos, en la cual se habían bordado geométricamente distintas sedas, siendo protagonista el oro.

Esta indumentaria exterior del rey nos presenta diversas cosas a analizar: la utilización de los emblemas de Castilla y León, el empleo de ciertos colores y la aparición del águila. Obviamente, al llevar bordados los escudos reales en las vestiduras, sabemos que estamos frente al rey. Es algo a lo que se recurría profusamente aportando color, pero también identidad: estamos ante el monarca. El empleo de los tonos rojizos suele ser privativo de la realeza sobre todo, si son muy brillantes o fuertes -al ser consideradas más cercanas a Dios-, son distintivos de la dignidad regia. En el caso de la utilización en Castilla, los rojos son tonalidades referentes a la cruzada, identificando el color de la sangre. También se relacionaba este color con el amor espiritual, aunque en este caso es muy probable que se utilizara para exaltar al rey como vicario de Dios. El empleo de la plata en el fondo de los

32 Menéndez Pidal, F. 2011. Heráldica de la Casa Real de León y Castilla (siglos XII-XVI): 157-166. Navarra: Ediciones Hidalguía.

33 Aquí encontramos también el rico sudario que envolvía al rey Sabio, que tenía una decoración basada en leones y grifos.

34 Domínguez Rodríguez, A. 2010-2011. "Retratos de Alfonso X en el Libro de los Juegos de Ajedrez, Dados y Tablas". Alcanate: Revista de estudios Alfonsies, 7 (Ejemplar dedicado a: VII Semana de Estudios Alfonsíes): 147-162. De hecho, podemos ver ejemplos muy claros y parecidos a la túnica del rey (Libro de los Juegos: Escorial, ms. T.1.6, f.1) y, también, telas muy similares a las de otros objetos que aparecieron en su ajuar (Libro de los Juegos: Escorial, ms T.I.6., f.65), como los guantes. Asimismo encontramos ejemplos del ajuar en otras representaciones del rey Sabio que nos dibuja O'Callaghan, J.F. 1998. Alfonso $X$ and the Cantigas de Santa Maria: a poetic biography: 69-72. Leiden: Brill. leones en la túnica viene a ser un símil del blanco. Se identifica con un color divino, como análogo a la luz. Pero también es un color asociado a la guerra contra el infiel en Castilla por ser un color esencial en el escudo de este reino. ${ }^{35}$ Los colores esenciales del reino de Castilla, rojo y blanco, nos indican sangre y pureza: la sangre derramada por los cristianos que luchan para purificar sus tierras de los infieles.

La aparición del águila en las prendas de este rey hace referencia al Imperio, algo a lo que Alfonso $\mathrm{X}$ dedicó gran parte de sus esfuerzos durante su reinado. También podemos observar otro bordado de águilas en una de las almohadas funerarias, con las alas abiertas. Este tipo de águila es la que conocemos con el nombre de "águila española", muy empleada también por los Reyes Católicos. Asimismo, el águila es un símbolo de los gibelinos, ${ }^{36}$ círculo al que pertenecía Alfonso, ya que era hijo de Beatriz de Suabia.

Las mencionadas almohadas funerarias eran tres. Hallamos una de ellas realizada con un forro de tafetán rojo con aspas de plata dorada. Una segunda almohada estaba decorada en cuadrícula con leones y castillos, algo que se copió en la tercera, en la que también se situaron unas cuantas águilas. Esta iconografía y el color de la primera almohada nos devuelve a la misma intención de la túnica exterior: al ver al monarca descansando en su lecho de muerte, vemos al rey de Castilla y León, un rey guerrero que lucha por su reino y la Cristiandad. Pero también nos muestra al emperador legítimo, o al menos eso pensaba fervorosamente Alfonso X. Sobre estas almohadas descansaba la cabeza del rey Sabio, que lucía ataviada con un gorro de lienzo grueso, forrado con tela carmesí y bordado por completo con perlas, coral y vidrio. Estos bordados creaban cruces que se enmarcaban con plata dorada. Estas son las únicas referencias a la cruz o al cristianismo que vamos a encontrar de forma directa en esta tumba. Es cierto que el monarca se nos presenta como un rey restaurador de la cristiandad en batalla, pero más allá de eso, debemos acudir a la utilización de ciertos colores para ver el acercamiento al cristianismo, por eso la importancia de estas pequeñas cruces en el gorro.

Sin duda, los elementos fundamentales que acababan de dar forma a este enterramiento eran los elementos metálicos, tales como la corona, la espada, el cetro... Es en la última apertura de 1948 cuando se vio que habían desaparecido. Gracias a los autores de los siglos XVI al XVIII podemos intentar dar forma a este ajuar perdido y componer así, el significado completo del enterramiento.

La espada, junto con las espuelas, ${ }^{37}$ vuelve a cerrar su significado en torno al derecho de conquista, la cruzada y el sentir caballeresco. Alfonso X la llevaba ceñida, no sobre el pecho ni las piernas. En este caso, hace referencia a los valores de un rey guerrero y caudillo de sus huestes. Alfonso se

35 González Arce, J.D. 1998. Apariencia y poder: la legislación suntuaria castellana en los siglos XIII y XV: 58-59, 124-125. Jaén: Universidad de Jaén.

36 Monreal Casamayor, M. 2006. "De Sermone Heráldico II: El Águila". Emblemata: Revista aragonesa de emblemática, 12: 289-334, para la identificación con los gibelinos: p. 298.

37 Éstas sí se conservan. Son de hierro y conservan la decoración de castillos y leones. Se sujetaban con cintas de cuero. 
presenta como monarca que lucha contra el infiel y defiende a su pueblo en pos del Bien Común. También es un elemento que representa la justicia en el reino, es un objeto que sitúa al monarca como juez y legislador, además de mano ejecutora. ${ }^{38}$ Hipotéticamente, podríamos decir que si el rey Sabio decidió llevar la espada a su cintura, es porque pretendió dar más importancia a otros elementos regios indispensables, además de otros enseres imperiales.

Otro de los instrumentos esenciales de la monarquía es la corona, elemento con el que se enterró Alfonso X, como nos cuentan Alonso de Morgado ${ }^{39}$ y Diego Ortiz de Zúñiga. ${ }^{40}$ Los datos que nos aportan sus textos no nos detallan con exactitud cómo era la corona: a veces simplemente la mencionan y otras veces la adjetivan como corona imperial. Lo único que parecía que sabíamos ciertamente es que era dorada y con piedras preciosas, ${ }^{41}$ algo que, además, el rey Sabio había estipulado en las Partidas, ${ }^{42}$ siendo la finalidad de una corona de oro y piedras preciosas que el monarca fuera reconocido públicamente. En 2009, Teresa Laguna recoge un inventario de joyas y ornamentos que se realizó en 1500, y aparece en la tesis doctoral de María del Monte Merchán..$^{43}$ En el inventario se describe la corona de Alfonso $X$. Dicen que era de oro y debía estar realizada a través de distintas piezas o placas encadenadas. En la zona de cada encadenamiento, éste se había recubierto de aljófar y sobre él se elevaba una cruz también de oro con una pequeña esmeralda y cuatro perlas también pequeñas. En cada placa había piedras preciosas engarzadas, alternando entre zafiros y balajes. ${ }^{44} \mathrm{~A}$ su vez, en las placas se alzaban cruces pequeñas en las que se volvían a disponer zafiros o balajes, pero al contrario de las piedras dispuestas en la parte central de las placas. Nos dan a conocer que todas las piedras eran verdaderas y de fino tallado, excepto un balaje que era falso. Con la descripción planteada, debemos decir que se desconoce si la corona fue realizada exprofeso para enterrarse con ella ${ }^{45} \mathrm{o}$ si es con la que aparece retratado

38 Flori, J. 1983. L'Ideologie du glaive. Préhistoire de la chevalerie. Ginebra: Droz; Nieto Soria, J.M. 1993. Ceremonias de la realeza: propaganda y legitimación en la Castilla Trastámara: 188-190. Madrid: Editorial Nerea; Palacios Martín, B. 1976. "Los símbolos de la soberanía en la Edad Media española. El simbolismo de la espada", en VII Centenario del infante don Fernando de la Cerda: 273-296. Ciudad Real: Instituto de Estudios Manchegos.

39 Morgado, A. 1587, libro IV: 108.

40 Ortiz de Zúñiga, D. 1796, tomo IV: 95 y tomo V: 321-322.

41 También sabemos que en el libro de los Castigos de Sancho IV, esta corona de oro abierta con piedras preciosas, era llevada por los emperadores: O'Callaghan, J.F. 1998. Alfonso $X$ and the Cantigas de Santa Maria: a poetic biography: 69-72. Leiden: Brill.

42 Partida II, título 5, ley 6.

43 Merchán Cornello, M.M. 1958. Historia de la Capilla Real de Sevilla, Tesis de licenciatura dirigida por el profesor Julio González y defendida el 28-02-1958 en la Facultad de Filosofía y Letras de la Universidad de Sevilla. Apéndice documental № 4: 294-303.

44 Rubíes de color rojo muy oscuro con reflejos violáceos. Tanto estas piedras como las que saldrán más adelante, se han buscado en el Lapidario sin haber obtenido resultados.

45 Nieto Soria nos comenta la pauta común de hacerse enterrar con una corona funeraria carente de valor, aunque es algo que, en el caso de Alfonso X, no podemos ni afirmar ni desmentir Nieto Soria, J.M. 2001. "La coronación del rey: los símbolos y la naturaleza de su poder", en Miguel Rodríguez Llopis (coord.), Alfonso $X$ y su época: el siglo del rey sabio: 127-152. Barcelona: Carroggio. en algunas de sus obras, como el Libro de los Juegos. ${ }^{46}$ De cualquier manera, nos permite decir que, en el caso de los ritos funerarios, la corona sí debía tener valor ceremonial. ${ }^{47}$ De hecho, sabemos que Alfonso $X$ se corona a sí mismo tras el fallecimiento de su padre, ${ }^{48}$ lo cual no le resta valor a la corona como elemento, es un símbolo de la monarquía que él no desaprovecha y utiliza a conveniencia.

Es fundamental la utilización del oro y los elementos dorados que se hallan en el ajuar, de cara al papel de vicario de Dios del que disfrutaba Alfonso. El oro se considera el metal más perfecto y precioso por su carácter ígneo y brillante. Se pensaba que Dios era luz en estado puro y transmitía esa luz a los seres creados, transmitiendo éstos mismos luz del Creador dependiendo de la posición que ocupen en el pensamiento jerárquico de Dios. ${ }^{49}$ Esto permitía que Alfonso $X$, al ser el monarca el único que podía llevar coronas de oro, se pudiera situar como vicario de Dios en la tierra, ya que -gracias a la teoría del color-jerárquicamente estaba ubicado junto a Dios, sin intermediarios. Además, el oro hace referencia a Jesucristo como Dios hecho carne, es la unión del alma con Dios. ${ }^{50}$ Sin duda, estos paralelismos debían ser muy útiles para el rey Sabio, ya que permitían reforzar su poder independiente sin tener que someterse a otros poderes del reino, ya que él está revestido de luz divina, sigue el camino que conduce a Dios.

Asimismo, las piedras preciosas también se entienden como luz congelada, luz que se podía ver y tocar. La piedra en origen -en bruto-, es creada por Dios, así que la piedra preciosa trabajada es el reflejo de Dios en ella. Usarlas en los instrumentos de poder significaba llevar a Dios consigo, motivo por el que también su uso estaba restringido a ciertos estamentos sociales. ${ }^{51}$ Esto lo podemos relacionar también con los tres anillos de oro con piedras que aparecieron en la tumba de Alfonso X. En la apertura de 1677 se anota la existencia de tres anillos, que tenían cada uno una piedra de distinto color: verde, rojo y blanco. El verde simboliza la esperanza, el rojo la caridad y el blanco la fe, ${ }^{52}$ lo cual nos conduce a las tres virtudes teologales. Obviamente, ya hemos visto que el rojo podía tener otros significados, al igual que el blanco, pero encontrar estos tres colores unidos sin duda pueden conducirnos a estas virtudes tan perseguidas por los buenos cristianos en el Medievo. Además, se debe tener en cuenta que no nos describen las piedras como piedras preciosas, lo cual puede hacernos pensar que

46 Libro de los Juegos: Escorial, ms. T.1.6, f.1 y f.65 en: Domínguez Rodríguez, A. 2010-2011. "Retratos de Alfonso X en el Libro de los Juegos de Ajedrez, Dados y Tablas". Alcanate: Revista de estudios Alfonsíes, 7 (Ejemplar dedicado a: VII Semana de Estudios Alfonsíes): 147-162.

47 En O'Callaghan, J.F. 1998: 69-72, se nos dice que Alfonso $X$ dio en prenda una de las coronas de oro a los Benimerines a cambio de un préstamo. También nos cuenta que esa corona acabó en Marrakech, así que no sabemos si sólo tenía una corona de oro o varias.

48 Ballesteros Beretta, A. 1984: 54.

49 Panofsky, E. 1979. El significado en las artes visuales: 150-157. Madrid: Alianza Editorial: esta jerarquía se aplicaba a todos los objetos suntuarios y sus cualidades.

50 González Arce 1998, pp. 56-59, 68, 124-125.

51 Ídem.

52 Ibídem: 58. 
no brillaban como tal, lo que afirmaría esta hipótesis que nos acerca a las virtudes regias.

Dos elementos más con los que se enterró Alfonso $X$ son un cetro y un báculo. Es Ortiz de Zúñiga el que nos informa de que es un báculo imperial..$^{53}$ Ante esto, nos surgen tres hipótesis al intentar interpretarlo ideológicamente. Primeramente acudimos a la tradición para explicar ambos elementos. Bango Torviso recuerda que los dos son instrumentos que han sido utilizados por los monarcas Peninsulares desde los tiempos visigodos. De los reyes asturianos en adelante se usaba el cetro, ${ }^{54}$ y se sabe que fue uno de los objetos más simbólicos y característicos en las representaciones iconográficas de la realeza en ciertas ceremonias. ${ }^{55}$ De las palabras de Bango Torviso se deduce que la aparición de un báculo o un cetro, dependía más de la elección del monarca en cuanto a las insignias reales, aunque también es cierto que pueden sufrir cierta equiparación que sólo les diferencia en el tamaño, interpretándolos como un cetro largo y un cetro corto. De todas maneras, en ellos vemos la tradición al llevarlos $\mathrm{y}$, aunque Alfonso $\mathrm{X}$ no los trate en las Partidas, es el mismo rey Sabio el que se entierra con ambos, dando una imagen de poder supremo.

El significado de ambas piezas reales se cierra en torno al simbolismo de la autoridad, que se deriva del bastón que utilizaban los pastores para guiar su rebaño. Dentro de la autoridad, se relaciona con el mando y gobierno, la virtud, la verdad y la justicia, ${ }^{56}$ además de ser un símbolo válido para aludir a los derechos sucesorios, que encierran la legitimidad y la continuidad dinástica. ${ }^{57}$ Igualmente puede tener dos significados más en nuestro contexto, ya que Alfonso $X$ pretendía de forma seria y obsesiva el trono imperial, ${ }^{58} \mathrm{y}$ asimismo tenía verdadero interés en situarse sobre todos los poderes de su reino. Como ya se ha mencionado, el báculo con el que se entierra Alfonso debía tener ciertas insignias imperiales, ${ }^{59}$ es decir, la decoración superior haría alusión al Imperio. ${ }^{60}$ Por ello, enterrarse con este báculo puede significar la confirmación de sus pretensiones, ${ }^{61}$

53 Ortiz de Zúñiga, D. 1796.

El báculo de emperador de Alfonso $X$ también surge en los trabajos de Linehan, P. 2012: 470 y O'Callaghan, J.F. 1998: 69-72, aunque tan sólo mencionan que se enterró con él tal y como nos dice Ortiz de Zúñiga.

54 Bango Torviso, I.G. 2001. "De las insignias reales en la España medieval", en Imágenes y promotores en el arte medieval: miscelánea en homenaje a Joaquín Yarza Luaces: 64-66. Barcelona: Universidad Autónoma de Barcelona.

55 Nieto Soria, J.M. 1993: 187.

56 Serrano Coll, M. 2011. "Los signos del poder: regalías como complemento a los emblemas de uso inmediato". Emblemata: Revista aragonesa de emblemática, 17: 136-139.

57 Nieto Soria, J.M. 1993: 187.

58 Ejemplos de ello nos dan diversos autores como por ejemplo: Ballesteros Beretta, A. 1984: 175-253, 409-411, 454-475, 674-734; Valdeón Baruque, J. 2003. Alfonso X el Sabio: la forja de la España moderna: 61-76. Madrid: Temas de hoy; González Jiménez, M. 2004. Alfonso X, el Sabio: 73-128, 205-209, 273-293. Barcelona: Ariel.

59 Es por esto que Ortiz de Zúñiga lo trata como tal: Ortiz de Zúñiga, D. 1796.

60 Aunque sabemos que también podía tener otras insignias como las reales o los escudos de armas en otras ocasiones: Bango Torviso, I.G. 2001: 64-66.

61 Monterde García, J. 2007. «El sueño imperial Alfonsí en "Las Siete Partidas"». Murgetana, 117: 9-18. ya que él se presentaba convencido de que estaba reclamando algo que le pertenecía por herencia, por la sangre recibida de su madre.

Igualmente, no se puede obviar que Alfonso X pretendía la superioridad sobre todos los poderes de su reino, entre ellos la Iglesia, motivo por el cual no duda en situarse como vicario de Dios y cabeza y alma del reino: ${ }^{62}$ no tiene a nadie sobre él que no sea Dios. El báculo, en este caso, podría simbolizar la superioridad sobre todos los poderes del reino e incluso sobre el Papado, al menos en cuestiones temporales. ${ }^{63}$ Es por esto que se debe estudiar este elemento como símbolo típico del poder episcopal, lo cual nos recuerda que el sacerdocio tiene sanción divina a través de la ordenación apostólica. Con esto no se pretende decir que Alfonso $X$ ostentaba algún poder espiritual, sino que el rey conocía la simbología del báculo y que el llevarlo lo convertía en emperador y rey, lo cual es sólo una decisión divina. Además, el báculo episcopal es símbolo del oficio de Pastor, es aquel que corrige vicios y juzga, que impulsa el cumplimiento de las virtudes y cuida de sus súbditos. ${ }^{64}$ Estas virtudes nos conducen al rey sacralizado y cristianísimo, que encuentra su legitimación a través de la imagen del poder real centrada en el teocentrismo. Así entenderíamos, hipotéticamente, que el hecho de llevar este instrumento sitúa al rey Sabio en torno al poder universal imperial, y que sus títulos no dependen del Papado, sino sólo y únicamente de Dios.

Un último elemento de su ajuar que se debe mencionar es el esqueleto de un perro pequeño que aparece a los pies del rey ${ }^{65}$ Sabemos que estos animalitos se situaban en ocasiones en la obra escultórica que cubría el sepulcro, lo inusual es encontrarlo dentro de la tumba. Es posible que su significado hable de la posición económica del difunto, aluda a la caza y simbolice la fidelidad ${ }^{66}$-algo que tanto apreciaba Alfonso $X$ y que tan poco obtuvo de algunos de sus vasallos-. También es probable que cumpla el papel de acompañar en la muerte a su dueño, como animal fiel, no le dejaría jamás solo en ese trance: vigilaría su sueño por siempre.

Como hemos visto hasta aquí, el ajuar del rey Sabio es bien amplio y detallista, evitando dejar símbolos al azar. Todo parece bien escogido para acompañar al rey en su último viaje y, a la vez, esbozar su ideología, pero ¿qué falta entre sus pertenencias? En su testamento final dice:

E otrosi mandamos, que luego que finaremos, que nos saquen el corazon e lo lleven a la Sancta tierra de Ultramar, e que lo sotierren en Jherusalem, en el monte Calvario. ${ }^{67}$

62 Partida II, título 1, ley 5.

63 En la Partida II, título 1, leyes 1, 2 y 3, se explica que el Papado sólo tendría poder en las decisiones espirituales, por lo que la corona Imperial no debería ser él quien la entregara, sino la herencia transmitida.

64 Arco y García, F. 2012. "Heráldica eclesiástica". Emblemata: Revista aragonesa de emblemática, 18: 140; Cendón Fernández, M. 2007. "Arte y poder episcopal en la Castilla de los Trastámara". E-Spania: Revue électronique d'études hispaniques médiévales, 3.

65 Delgado Roig, J. 1948: 138.

66 Morales Cano, S. 2011. "La escultura funeraria gótica en la provincia de Toledo". Anales de historia del arte, 1 (Ejemplar dedicado a: Saberes artísticos bajo signo y designios del "Urbinate"): 363.

67 Testamento reproducido en: Ballesteros Beretta, A. 1984: 1051. 
Es decir, lo que falta en el sepulcro de Alfonso $X$ es el corazón. Delgado Roig muestra en su estudio forense la existencia de dos cortes quirúrgicos en la caja torácica del rey Sabio que sirvieron para poder sacar su corazón y sus vísceras. ${ }^{68}$ Sabemos que el monarca guardaba gran amor a Murcia y Sevilla por haberse mantenido fiel a él durante la rebelión del infante Sancho, por ello, su testamento indica en varias ocasiones que si no descansa en Murcia, quiere hacerlo en Sevilla. Hoy en día conocemos como terminó esta cuestión: el rey fue enterrado en Sevilla junto a sus padres y su corazón fue a parar a la catedral de Murcia, ${ }^{69} \sin$ llegar a tener la opción de llegar a Tierra Santa.

Y también se dice:

Mandamos otrosi, que quando sacaren el nuestro corazon para llevarlo a la Sancta tierra de Ultramar, segund es ya dicho, e que saquen lo otro de nuestro cuerpo e lo lleven a enterrar al monasterio de Sancta Maria la Real de Murcia, o a do el nuestro cuerpo oviere de ser enterrado, que lo metan todo en una sepultura. ${ }^{70}$

Este fragmento de su testamento muestra la necesidad que tenía Alfonso de conservar su cuerpo lo más incorruptible que fuera posible, evitando que los órganos internos propiciaran la descomposición del cadáver. La intención de conservar el cuerpo tenía su finalidad en dar indicios de santidad, ${ }^{71}$ al igual que se hacía al embalsamarlos, intentando que se conservaran. Esto propiciaba la aparición de diversos lugares de enterramiento para una sola persona. Tenemos otros ejemplos en la historia que se sumaron a esta moda de enterramiento medieval como Guillermo el Conquistador, Carlos V de Francia o su condestable Bertrand Du Guesclin. Podían llegar a existir hasta cuatro depósitos funerarios: uno para el corazón, centro esencial de vida en el cuerpo; otro para las vísceras, que tienden a la corrupción; la carne como elemento tendente al pecado; y los huesos, considerados la parte más noble del cuerpo, seguramente por ser la más duradera. ${ }^{72}$ Es por esto que, al leer este fragmento del testamento del rey Sabio, vemos que pretendía que su corazón fuese a Jerusalén, que sus vísceras se extrajeran del cuerpo y que, separadas del mismo, fueran enterradas junto con el cuerpo en una misma sepultura. La finalidad es obvia: conservar lo más incorruptiblemente posible su cuerpo, seguramente intentando lograr algún tipo de santidad ${ }^{73}$ al igual que la obtuvo su padre. Además, Alfonso $X$ fue embalsamado con sustancias muy poco usuales -como son las resinas de estoraque y benjuí-, lo cual indica que se debieron conseguir exprofeso para embalsamar a ciertos personajes de renombre o al mismo rey. ${ }^{74}$ Esto nos muestra otro intento más para que su cuerpo perdurase en el tiempo, así el rey siempre estaría presente aunque

68 Delgado Roig, J. 1948: 138.

69 Torres Fontes nos cuenta los detalles de cómo acabó allí su corazón: Torres Fontes, J. 2002. "El corazón de Alfonso X el Sabio en Murcia”. Murgetana, 106: 9-15.

70 Ballesteros Beretta, A. 1984: 1052.

71 Aries, P. 1983. El hombre ante la muerte: 218-219. Madrid: Taurus; Mitre Fernández, E. 1988: 180.

72 Mitre Fernández, E. 1988: 180.

73 Ídem.

74 Delgado Roig, J. 1948: 147-148. fuera en cuerpo y no en alma. A la vez, esto plantea un interrogante: si Alfonso X pretendió que su corazón y sus vísceras no estuvieran en el mismo sitio enterradas, y nunca se ha descubierto en su sepulcro ningún recipiente a modo de vaso canope donde albergar las entrañas, ¿dónde acabaron descansando sus vísceras?. ${ }^{75}$

\section{Ajuar de Sancho IV}

Sancho IV pidió enterrarse en el mismo lugar donde se coronó por primera vez: Toledo. Llama la atención que se hiciera coronar por varios obispos, ${ }^{76}$ ya que era una tradición que se estaba perdiendo, pero más interesante es que lo hiciera dos veces - una en la catedral de Toledo ${ }^{77}$ y otra en la de Sevilla- ${ }^{78}$ aunque esto encuentra su explicación en la legitimación de su papel en el trono, frenando la ambición de los nobles establecidos en Sevilla que habían estado en torno a Alfonso $\mathrm{X}$ en los enfrentamientos sucedidos entre 1282 y 1284 . Sancho IV falleció a los 36 años.

En las Crónicas que recopila Rosell, queda todo muy bien tratado, haciendo que todo nos parezca muy ritual y visual. ${ }^{79}$ Cuando Sancho IV cree que está ante sus últimos momentos de vida, lo primero que hace es establecer la regencia que encabezaría María de Molina. Tras esto, manda que la corte se desplace a Toledo. Al entrar en la ciudad, fízose llevar en andas en cuellos de omes á la cibdad de Toledo. El rey Bravo se muestra ante sus súbditos, enfermo y deteriorado, por lo que sólo puede esperar allí su muerte. Pasa un mes de espera y cuando se sintió sin fuerzas se confesó, tomó la Eucaristía y se mandó ungir, recibiendo así todos los sacramentos de Santa Iglesia como un rey muy católico. Poco después murió, y con ello vino el llanto de sus familiares y el reino.

Aquí se observa un mayor detalle tanto de los actos que se realizaron como de las fechas. Sancho fallece un 25 de abril después de medianoche. Al día siguiente se sigue con el llanto, pero ya se lleva el cuerpo a la iglesia de Santa María de Toledo para oficiar una misa por su alma y enterrarle en la Capilla de la Santa Cruz junto a Alfonso VII. En este funeral aparece la reina María de Molina, el infante y futuro rey Fernando, los grandes omes, el arzobispo de Toledo y toda la clerecía, las órdenes, los ricos omes con toda la caballería

75 Se debe mencionar que estudiosos como Antonio Ballesteros, Manuel González Jiménez o Juan Torres Fontes, que han trabajado el reinado del Sabio de forma intensa, no han aportado luz a este asunto. En algunos casos se da por sentado que las vísceras están en Murcia, pero no se hace ninguna referencia a fuentes o bibliografía que solucionen la duda.

76 Ruiz, T.F. 1987.

Además, Peter Linehan nos presenta el debate abierto por los historiadores sobre si estuvo o no estuvo la reina en la coronación, además de la asistencia del arzobispo de Toledo. También incorpora la ideología unida a la coronación: Linehan, P. 1986. "Pseudo-historia y pseudo-liturgia en la obra Alfonsina”, en España y Europa: un pasado jurídico común: 259-274. Murcia: Universidad. Instituto de Derecho Común.

77 Nieto Soria, J.M. 1988b. Iglesia y poder real en Castilla: el episcopado, 1250-1350: 59. Madrid: Universidad Complutense de Madrid.

78 Nieto Soria, J.M. 1994: 70; Gutiérrez Baños, F. 1998. Las empresas artísticas de Sancho IV El Bravo: 70. Burgos: Junta de Castilla y León - Consejería de Educación y Cultura.

79 Rossel, C. 1875-1878: Crónica de Sancho IV, capítulo XII y XIII. 
y el pueblo de Toledo. Como expresa, el gentío era impresionante, por lo que creemos que no sólo era por el funeral regio. En cuanto metieron a Sancho IV en su sepulcro pétreo, en el Altar Mayor de la catedral recibieron por rey y señor a Fernando IV. Es decir, tanta gente tiene un motivo fundamental: dar a conocer la existencia del nuevo rey $y$, por tanto, la continuidad dinástica, al igual que la legitimidad, que se daba de forma automática al aceptarlo todo el reino presente. Así visto, parece que no se estaba haciendo mucho caso al "rey muerto", sino más bien al "rey puesto". Pero la disposición de la actual Capilla Mayor de la catedral de Toledo, sabemos que permitía observar en un mismo conjunto, aunque en ámbitos separados, a ambos monarcas. Es decir, de forma simbólica, nos permitían ver la continuidad.

Por otra parte tenemos la crónica de Loaysa, la cual no es muy detallista, pero al menos sí lo es más que con Alfonso X. Gracias a Jofré, sabemos que Sancho tuvo un reinado breve pero efectivo, lo cual pretende demostrar a través de sus diversos elogios al rey Bravo. Igualmente, nos permite conocer que Sancho tomó antes de morir el hábito de la orden de san Francisco y que falleció de tisis, el nombre que se le daba a la tuberculosis. ${ }^{80}$ Esta enfermedad de difícil diagnóstico, fue muy mortífera durante la Edad Media llegando a llamarla "peste blanca" por algunos estudiosos. ${ }^{81}$

Igualmente, es en la Crónica de Jofré donde vemos que existía la tradición de que durante unos días se guardara algún tipo de luto por la muerte del monarca. Él habla de los días destinados al funeral regio, ${ }^{82}$ como ya hemos visto que el funeral les ocupó un día, hemos de pensar que se estipulaban unos cuantos días como luto "oficial".

Para asentar el sepulcro de Sancho IV, él mismo mandó erigir la hoy inexistente capilla de la Santa $\mathrm{Cruz}^{83}$ en la que

80 Loaysa, J.; García Martínez, A. (ed.) 1982: 159; Cabrera Sánchez, M. 2011: 103-104.

81 Mitre Fernández, E. 2004. Fantasmas de la sociedad medieval: enfermedad, peste, muerte: 57-58. Valladolid: Universidad de Valladolid.

82 Loaysa, J.; García Martínez, A. (ed.) 1982: 163.

83 "Testamento" de Sancho IV el Bravo dado el 14 de febrero de 1285 , Soria. Pergamino escrito en castellano con letra minúscula cursiva. 600 x 635 mm. Archivo Histórico Nacional de Madrid, Sección clero, carpeta 3022, no 5 bis. Publicado en Escudero de la Peña, J.M. 1872. "Privilegio miniado e historiado del rey don Sancho IV". M.E.A., tomo I: 98; Abad Castro, C. 2001. "Espacios y capillas funerarias de carácter real", en Isidro G. Bango Torviso (coord.), Maravillas de la España medieval. Tesoro sagrado y monarquía: 63-73. Valladolid: Junta de Castilla y León; Amador de los Ríos, R. 1903. "Los túmulos reales de la capilla mayor en la catedral de Toledo". La España moderna, 177: 88-115; Arco, R. 1954. Sepulcros de la Casa Real de Castilla. Madrid: Instituto Jerónimo Zurita. C.S.I.C.; Bango Torviso, I.G. 1992: 93-132; Bango Torviso, I.G. 2005. "La catedral de Toledo hacia 1400 . Un centro creador en constante transformación", en La capilla de San Blas de la Catedral de Toledo: 21-32. Bilbao: Fundación Iberdrola; Beltrán Torreira, F. 1990. "San Ildefonso de Toledo y el culto a la Virgen en la Iglesia hispano-visigoda: problemas históricos y doctrinales", en Devoción mariana y sociedad medieval actas del simposio. Ciudad Real del 22 al 24 de marzo, 1989: 439-454. Ciudad Real: Instituto de Estudios Manchegos; Fernández Collado, A 1999. "El retablo de la Capilla Mayor de la Catedral de Toledo". XX Siglos, Vol. 10, 42: 74-81; García Rey, V. 1922. "La capilla del rey don Sancho el Bravo y los cenotafios reales en la catedral de Toledo". Boletín de la Real Academia de Bellas Artes y Ciencias Históricas de Toledo, 3: 129-148; Gutiérrez Baños, F. 1998; Heim, D. 2003. “Entre Mendoza y Cisneros: la gestación del retablo mayor de la catedral de Toledo". Anales Toledanos, 39: 103-116; Moreta Velayos, S. 1996. "Notas sobre el franciscanismo y dominicanismo de Sancho IV y María de Molina”, en José Ignacio de la situarían los enterramientos de otros reyes -como Alfonso VII- con intención de dar legitimidad a su línea dinástica. ${ }^{84}$

En 1947 llega a Toledo el doctor Olivera Salazar de parte del gobierno portugués. Su intención era encontrar los restos del rey destronado Sancho Capelo. Su búsqueda es la que llevó a que se tuviera que abrir la sepultura de Sancho IV y, gracias a ello, se pueda estudiar hoy su indumentaria totalmente inusual. La apertura dejó a la luz el cadáver de Sancho IV, momificado y en un excelente estado de conservación. Una colcha finamente bordada guardaba el cadáver del rey, el cual se hallaba desnudo a excepción de un blanquecino calzoncillo, el cíngulo de la orden de San Francisco y el calzado. Los datos nos informan de que Sancho fue enterrado con el hábito de la orden franciscana ${ }^{85}$ y además, el rey debió ordenar que fuese enterrado con los elementos típicos de un rey y guerrero: la espada, la corona y los acicates.

Si analizamos poco a poco su ajuar, nos damos cuenta de que la finalidad de Sancho iba mucho más lejos de la mera propaganda política, ya que buscaba la legitimación de su reinado y por lo tanto, la posición segura de su hijo en el trono. Pero, además, veremos que era su manera de alcanzar la perfección como rey y, de este modo, un arma política.

La corona con la que fue enterrado ha dado lugar a debate por su origen, ya que se cree que puede ser una de las que Alfonso X legara en su testamento. ${ }^{86}$ Transmitida por herencia, se considera que la corona podía haber sido ceñida por Fernando III o Alfonso VIII ${ }^{87}$-ya que la heráldica señalaría a un rey de Castilla, pero no de León-, aunque también es posible que se realizara para Alfonso X. ${ }^{88}$ La corona se presenta formada por ocho placas de plata unidas por charnelas, sobre ellas se sitúan ocho castillos heráldicos; cuatro de las placas tendrían engarzados cuatro zafiros, las otras cuatro llevan cuatro camafeos, seguramente de procedencia romana, tallados en ágata y marfil.

Iglesia Duarte, Javier García Turza, José Ángel García de Cortázar y Ruiz de Aguirre (coords.), VI Semana de Estudios Medievales: Nájera, 31 de julio al 4 de agosto de 1995: 171-184. Nájera: Instituto de Estudios Riojanos; Nogales Rincón, D. 2009; Nogales Rincón, D. 2014: 257-282; Núñez Rodríguez, M. 1985. "Iconografía de humildad: el yacente de Sancho IV". Boletín del Museo Arqueológico Nacional, 3/2: 170-175; Rivera Recio, J.F. 1985. "Los restos de Sancho IV en la catedral de Toledo: crónica retrospectiva". Boletín de la Real Academia de Bellas Artes y Ciencias Históricas de Toledo, 16/año LXIX: 127-138; Ruiz Souza, J.C. 1998; Ruiz Souza, J.C. 2006: 9-30; Torija Rodríguez, E. 2014. "Las capillas funerarias reales de la catedral de Toledo. Elementos humanos y legitimadores", en María Dolores Teijeira Pablos, María Victoria Herráez Ortega y María C. Cosmen (coords.), Reyes y prelados: la creación artística en los reinos de León y Castilla (1050-1500): 283-295. Madrid: Sílex Ediciones.

84 Gaibrois de Ballesteros, M. 1922-1928. Historia del reinado de Sancho IV de Castilla, vol. 2: 24-26. Madrid: Tipografía de la Revista de Archivos - Bibliotecas y Museos; Moreta Velayos, S. 1996: 171-184; Núñez Rodríguez, M. 1985: 170-175.

85 Loaysa, Jofré de; Antonio García Martínez (ed.) 1982: 159.

86 Aparece en el testamento definitivo de Alfonso $X$ citado en: Ballesteros Beretta, A. 1984: 1053.

87 Schramm, P.E. 1960. Las insignias de la realeza en la Edad Media española: 35-41. Madrid: Instituto de Estudios Políticos.

88 Respecto a este tema, además de los ya citados respecto a su enterramiento: Relanzón García-Criado, J.M. 1959. "La corona y la espada de Sancho IV de Castilla". Boletín de la Real Academia de Bellas Artes y Ciencias Históricas de Toledo, 69-70-71: 24-32; Gutiérrez Baños, F. 1998. 
Teniendo en cuenta que la corona es el símbolo distintivo de la monarquía por excelencia, observamos que los elementos de este emblema le dan una serie de valores indispensables como rey. Primeramente, vemos la utilización de los castillos heráldicos, idénticos a los que se encuentran en las monedas castellanas de la época. Éstos nos trasladan a la identidad del reino: Castilla. En segundo lugar, el material principal de la corona es la plata, un metal que sólo el rey podía llevar en la cabeza. Este metal de refulgente brillo blanquecino es símbolo de lo divino, está unido estrechamente a Dios, a la luz como inicio de todo, a la inteligencia suprema y a la verdad absoluta. En tercer término, está la utilización de los zafiros, importantes por piedra preciosa y por su color. Se considera que la piedra bruta es creada por Dios, por lo que las piedras preciosas se tienen por luz divina congelada, palpable y visible. El color azul, durante el siglo XIII, se convirtió -junto con el rojo- en un color inherente a la función regia. Además el azul se relaciona con Jesús, con la Virgen, con el Espíritu Santo y la santificación que de todos ellos emana. También se le relaciona con la estabilidad. ${ }^{89}$

Esta evaluación nos conduce a situar esta corona en concreto como un elemento que vinculaba al rey Bravo con la divinidad: es esencial ver en ella un símbolo que fundamenta la posición y derechos de Sancho al trono como una decisión divina y, por lo tanto, estamos ante un rey sacralizado. Este es un paso más dentro de la sacralización buscada para el rey Bravo, como lo era también la intención de Álvaro Pelayo al otorgarle poderes taumatúrgicos. ${ }^{90}$ La decisión de Sancho en la utilización de la plata encuentra su justificación al saberse que el oro se ve como un metal que conduce a Dios, sin embargo, la plata es un metal que indica que la santificación está dentro de su persona: no es que Sancho vaya de camino a Dios, es que Dios está en él. También, se debe tener en cuenta que la utilización de la plata nos muestra que El Bravo estaba tocado por Dios y poseía la sabiduría divina, elemento esencial para guiar y enseñar el camino a su reino. Al enterrarse con la corona nadie más podría llevarla, quedando legitimado hasta en la muerte y fue, dado este supuesto, el único y verdadero rey de Castilla.

Otro elemento con el que se entierra Sancho IV es una espada lo cual tiene suma importancia, ${ }^{91}$ ganando casi en valor a la corona ya que su simbolismo se cierra en torno a lo justo y el derecho de conquista. La espada acompaña a muchos caballeros y nobles, así que no es de extrañar que también se utilice en enterramientos regios. ${ }^{92}$ La espada

89 González Arce, J.D. 1993. "El color como atributo simbólico del poder (Castilla en la baja Edad Media)". Cuadernos de arte e iconografía, 6, 11: 103-108; González Arce, J.D. 1998: 56-59, 65-68, 114-116, 124-125 y 129.

90 Nieto Soria, J.M. 1989: 62; Nieto Soria, J.M. 1997: 88; Gutiérrez Baños, F. 1998: 66

91 Es tan importante en su simbolismo que Palacios Martín incluso considera que el acto de investidura de armas se sitúa por encima al de la coronación: en Palacios Martín, B. 1988. “Investidura de armas de los reyes españoles en los siglos XII-XIII", en Bonifacio Palacios Martín (ed.), Las Armas en la historia (siglos X al XIV): Actas del Primer Simposio nacional sobre las Armas en la Historia, marzo 1983: 153-192. Jaraíz de la Vera: Gladius.

92 De hecho, otra pieza que convierte a los hombres en caballeros son todos los elementos relacionados con la monta de caballos, en el caso de Sancho, fue enterrado con acicates de hierro sobredorado que situada sobre el pecho, no sólo hace referencia a valores guerreros, también adopta la forma de un crucifijo, dando fe de la religiosidad de la persona sobre quien descansa y la lucha por la fe cristiana. ${ }^{93}$ Teniendo en cuenta la situación de los reyes en la Península Ibérica, la espada era un emblema de la lucha contra el infiel, lo cual se consideraba una necesidad. El rey se presenta como caudillo de Dios, que guía a su pueblo contra el infiel en busca de la defensa del cristianismo. Sancho IV era el jefe supremo del ejército, un rey guerrero, que a su vez defendía a la Iglesia de su reino. También era el protector de sus naturales y del Bien Común. Igualmente, la espada es un símbolo que representa la justicia, la cual reposa en las manos del rey. Es la manera de representar al monarca como jefe de la legislación del reino, de la justicia y su ejecución, además de gobernar y administrar. ${ }^{94}$

Respecto a la vestimenta que presentaba el rey Bravo a la hora de ser enterrado existe un debate abierto. Rivera Recio se presenta como testigo visual de aquel descubrimiento dando fe en su escrito de lo que vio y de las irregularidades que se llevaron a cabo. Critica que hubo "olvidos incomprensibles", ya que nadie tomó medidas del ataúd, ni de los restos, no se tomaron fotografías, ni se tomaron apuntes o dibujos de lo allí hallado. Él, como testigo, nos presenta amortajado a Sancho con una especie de calzoncillo blanquecino y rodeando su cintura estaría el cíngulo de San Francisco como símbolo de humildad, pobreza y penitencia, pero calzado con cuero fino y espuelas. Afirma que es el cardenal-arzobispo de Toledo, don Enrique Pla y Deniel, el que cubrió los restos momificados de Sancho IV con un hábito franciscano para las fechas de la exhumación. ${ }^{95}$ Por otra parte, Moreta Velayos afirma que Sancho se hizo enterrar con hábito franciscano, ${ }^{96}$ compartiendo opinión con Núñez Rodríguez que establece que el rey Bravo habría sido enterrado descalzo y con hábito franciscano. ${ }^{97}$ Gutiérrez Baños asegura que Sancho IV fue enterrado con hábito franciscano, del que sólo se conservó bien el cíngulo, además de calzado y con espuelas. ${ }^{98}$

Todas estas interpretaciones dispares nos alejan de la realidad y complican el horizonte investigador ya que para poder dejar cerrado este debate se debería volver a exhumar al rey Bravo y hacer estudios en condiciones sobre todo el sepulcro. Sin embargo, las aportaciones de otros investigadores nos pueden conducir a vislumbrar la realidad de este asunto. Los hábitos franciscanos estaban tejidos con lana, material que hoy sabemos que es de fácil degradación. La naturaleza de esta fibra, los diversos tintes utilizados en su manufacturación y las condiciones del enterramiento son factores de gran relevancia que determinan la degradación

tenían abundante decoración en relación al reino de Castilla, además de que debieron estar esmaltados: Gutiérrez Baños, F. 1998: 86-87.

93 Morales Cano, S. 2011: 360-362.

94 Gutiérrez Baños, F. 1998: 66-67, 69, 85.

95 Rivera Recio, J.F. 1985: 132.

96 Moreta Velayos, S. 1996: 181

97 Núñez Rodríguez, M. 1985.

98 Gutiérrez Baños, F. 1998: 94. 
de la lana. ${ }^{99}$ Esto nos podría llevar a pensar que Sancho, efectivamente, se enterró con un hábito franciscano, el cual ha desaparecido por la desintegración de la lana y el paso de los años.

Aún con el debate candente, es cierto que Sancho renunció a ciertos elementos que subrayan la dignidad real aunque tomó otros a cambio. Moreta Velayos cree que esto es así como prueba de compromiso del rey con los franciscanos, pero hay que tener en cuenta que Sancho falleció convencido de que su defunción no se debía a ninguna dolencia natural. El monarca creía que la verdadera causa de su muerte radicaba en sus pecados, apesadumbrado en exceso por haber sido maldecido por su padre, era bastante probable que se mostrara sumamente arrepentido. ${ }^{100} \mathrm{En}$ los franciscanos encontraría un modelo de referencia por cómo preparaban al individuo de cara a la muerte, intentando remediar sus malos actos del pasado. ${ }^{101}$

Ciertamente, los valores franciscanos, como la humildad y la pobreza, no estaban presentes en la vida del rey Bravo, pero casaban de forma excelente con la ideología que Sancho quería plasmar en su muerte. Los laicos tomaban el hábito penitencial, sobre todo, para el indulto de sus culpas. Sancho IV se había presentado ante don Juan Manuel como responsable de su muerte y destino. ${ }^{102}$ De su arrepentimiento público podemos dilucidar que el rey Bravo se debía sentir culpable de los sucesos acaecidos con su familia. Aceptaba su culpa y buscaba la reparación de sus pecados. Si escogió el hábito franciscano es porque esta orden inculcaba el ideal de perfección cristiana y también el arte del bien morir para un cristiano. Sancho tenía muy presente que iba a vivir un juicio individual que podía alejarle de la buena muerte, de ahí su penitencia al vestir el hábito franciscano y desprenderse de sus vestimentas regias. Con el hábito en la tumba, se hacer honor a San Francisco, intentando que el santo actúe como interlocutor ante Dios para redimir la pena del rey difunto. Otro motivo para llevar el hábito es que el atuendo sirviera como guía moral para la sociedad de la época, ${ }^{103}$ recurriendo así a la imagen de rey virtuoso y cristiano que refleja las virtudes típicas de la vida cristiana, las virtudes teologales y las cardinales. De aquí también surge un significado político y es que, si las órdenes mendicantes cumplían votos de obediencia, deberíamos pensar que la única obediencia que debía tener el rey era hacia Dios, y jamás ante otros poderes del reino. Definitivamente, la utilización del hábito franciscano

99 Solazzo, C; Dyerb, J.M.; Clerensb, S.; Plowmanb, J.; Peacocke, E.E.; Collins, M.J. 2013. "Proteomic evaluation of the biodegradation of wool fabrics in experimental burials". International Biodeterioration \& Biodegradation, 80: 48-59.

100 Gaibrois de Ballesteros, M. 1922-1928, vol. 2: 373 y en Núñez Rodríguez, M. 1985.

101 Nieto Soria, J.M. 1997.

102 Don Juan Manuel; Alvar C. y Finci S. (ed.) 2007. Libro de las Armas, en Don Juan Manuel. Obras completas: 992-997. Madrid: Biblioteca Castro, Fundación José Antonio de Castro.

103 Núñez Rodríguez, M. 1988. "La indumentaria como símbolo en la iconografía funeraria”, en Manuel Núñez Rodríguez, Ermelindo Portela Silva (coords.), La idea y el sentimiento de la muerte en la historia y en el arte de la Edad Media: Ciclo de conferencias celebrado del 1 al 5 de diciembre de 1986: 9-19. Santiago de Compostela: Universidade de Santiago de Compostela. tiene tres grandes funciones para Sancho IV: responder al ejercicio de poder propio de la realeza, el cumplimiento de la ideología que lo sustenta y la remisión de sus penas ante el arrepentimiento sincero.

Otros elementos significativos del ajuar del rey Bravo son la colcha funeraria y la almohada. El rey renunció al manto escarlata típico de la realeza para cubrir su cuerpo, cambiándolo por una colcha de rica decoración y gran calidad, acompañado de una almohada funeraria con águilas ${ }^{104}$ y leones rampantes, que utilizaría rojos, verdes y blancos. Ambas piezas estaban realizadas con filosedas, decoradas con gran detalle y siguiendo el gusto mudéjar que impregnaba la Corte en estos años. Tanto el almohadón como la colcha estaban tintados con azules y rojos. ${ }^{105}$ Las tonalidades rojizas son colores típicos de la realeza y aluden, al igual que el azul, a la santificación y al Espíritu Santo. En Castilla tenían un significado especial al ser emblema de la sangre vertida en las batallas contra el infiel. También fue utilizado en la heráldica castellanoleonesa, ${ }^{106}$ lo cual vuelve a situar al rey en su lugar ante el reino.

Como se puede ver, el sepulcro del rey Bravo no iba dirigido únicamente a actuar como propaganda, es toda una declaración de intenciones y un modo de reforzar del poder regio. Es cierto que en él podemos ver todos los valores típicos de un buen cristiano, al igual que dejó muy bien expresado el pesar y el arrepentimiento que sentía por los malos actos cometidos. Pero también observamos que estamos ante la tumba de un rey que se preocupó por convertir su persona, de cara a la fama póstuma, en un ser perfecto que une en sí mismo el poder temporal y espiritual. La relación de todo el conjunto del enterramiento nos lleva a pensar que, aunque hiciera una renuncia formal a ciertos hábitos de la monarquía -eliminando el escarlata como color del poder y el oro como color que conduce a Dios-, a cambio tomó metales como la plata que es símbolo de lo divino, como si en él mismo estuviera $\operatorname{Dios}^{107}$ y no fuera necesario conducirle. Por esto, podemos afirmar que renuncia a ciertos símbolos de la realeza pero accede a otros que refuerzan más su poder. De hecho en su sepulcro, podemos encontrar todos los atributos de la perfección ideológica regia.

\section{CONCLUSIÓN: LA PERVIVENCIA DE LA IDEOLOGÍA REGIA EN LOS DISTINTOS AJUARES}

Al enfrentarnos a los sepulcros de Alfonso $X$ y Sancho $I V$, sin duda, sacamos una clara conclusión: todo el ajuar elegido y su colocación responden a un motivo concreto. Ambos monarcas se entierran como tales, dejando patente

104 Sancho IV debió emplear águilas en su colcha funeraria como símbolo de la continuidad dinástica, ya que fue un símbolo que ya había empleado su padre para la reclamación del trono imperial: Menéndez Pidal, F. 2011: 157-166; Monreal Casamayor, M. 2006: 289-334.

105 Gutiérrez Baños, F. 1998: 97.

106 González Arce, J.D. 1998: 58-59, 68, 124-125.

107 Nieto Soria, J.M. 1992. "Lo divino como estrategia de poder en Castilla (siglos XIII al XV)", en Sección cronológica = Section chronologique = Chronological Section, vol. II: 669-674. Madrid: Comité Internacional des Sciencies Historiques. 
que son los reyes de Castilla. Si miramos más allá, debemos adentrarnos en el significado del ajuar.

El mensaje que transmiten los sepulcros de ambos reyes se centra en la ideología o en la defensa de su reinado. Con el empleo de la espada, por ejemplo, hemos visto que los monarcas se presentan como jefes supremos del ejército, son reyes guerreros que luchan para defender la cristiandad y a sus vasallos. Eran protectores de sus naturales y su tierra, como buenos amantes y defensores del bien común. Igualmente, la espada les sitúa como cabezas de justicia y todo lo que de ella emana, así como de la legislación, su ejecución, el gobierno y la administración.

Asimismo, la utilización de ciertos colores o materiales sitúa a ambos monarcas como reyes que buscan la sacralidad y que su persona emane indicios de santidad: Alfonso lo pretendía con la buena conservación de su cuerpo y Sancho con sus poderes taumatúrgicos. Aunque diferente, en ambos monarcas vemos la necesidad de que su poder descanse sobre la emanación de Dios, siendo reyes por la gracia y decisión de la divinidad. El poder de ambos se fundamenta en una relación directa entre el monarca y Dios, siendo los reyes situados como tales. Estas cuestiones giran en torno a los principios teocéntricos y de sacralización del poder. Así, encontraron la fórmula para que el poder regio fuera incuestionable.

Podemos observar las diferencias de la siguiente manera. Por un lado, está Alfonso $X$, un rey que vestía principalmente en dorados y rojos. Su intención primordial era la superioridad del rey sobre todos los poderes del reino. El oro se presenta como un metal que conduce a Dios y, además, no estaba al alcance de todos según las leyes suntuarias. ${ }^{108}$ Esto es algo que ya de por sí le situaba por encima de otros. Obviamente, el estipular en las Partidas que sólo él como monarca puede lucir una corona de oro con piedras, también le distancia del resto de los poderes. Pero su necesidad le empuja también a completar su atuendo con otros instrumentos regios e imperiales: el cetro y el báculo. Como hemos visto, estos dos elementos responden a los símbolos por excelencia de la autoridad, la cual emana del rey como cabeza del reino y compendio de virtudes. Por otro lado aparece Sancho IV, un rey vestido de religioso que sólo destacaba por el empleo de una corona de plata que lucía sobre la cabeza. La intención del rey Bravo debía ser la de legitimarse en el trono. Las leyes suntuarias estipulaban que sólo el monarca podía llevar plata en la cabeza, así que eso ya le situaría como rey y cabeza del reino, un poder superior. Pero además, la plata indica que la santificación está dentro de una persona, ya que era un metal íntimamente unido a Dios. Esto -junto con los supuestos poderes taumatúrgicoscreaba a un rey rodeado de un halo sacro, algo que lo convertía en vicario de Dios y reforzaba su poder. Igualmente, la utilización de otros elementos, como una espada o una corona de otros reyes castellanos, pretende relacionarle con otros monarcas anteriores para reforzar la idea de continuidad dinástica, siendo otros ejemplos claros de legitimación.

Otra de las grandes diferencias entre ambos es la gran religiosidad que presenta Sancho en contraposición a su padre. Como hemos visto, Alfonso $\mathrm{X}$ sólo empleaba unas crucecitas de cuentas de vidrio bordadas sobre el gorro funerario. También vimos que empleó anillos con piedras de colores que, hipotéticamente, podían representar las virtudes teologales. Sancho, en cambio, se entierra vistiendo un hábito franciscano, alcanzando así la perfección religiosa de cara a la muerte. Hoy en día sabemos que esto tiene su explicación en el fuerte arrepentimiento y en el miedo que tenía Sancho. Temía por su alma, ya que le perseguían los errores del pasado. Eso le hizo tomar el hábito de la orden de San Francisco y emplear sus "artes del bien morir", convirtiéndole en un rey defensor de las virtudes teologales, cardinales y de la vida cristiana. No es que estemos ante un rey más religioso que otro, ambos vivían insertos en la sociedad de su época y compartían la religiosidad del ambiente. Existió un problema moral y un miedo evidente del rey Bravo, algo que le hizo temer la muerte como castigo divino. Alfonso no tuvo que enfrentarse de forma tan poderosa a un temor similar, él tenía sus propias preocupaciones, como la falta de fidelidad de los suyos, un valor importante que se ve simbolizado en un pequeño perro a los pies de su cuerpo.

Es decir, mediante el estudio de ambos ajuares $-y$ filtrándolos a través de las leyes suntuarias y del significado del color o los metales-, se consigue apreciar como los dos monarcas se acercaban a un mismo modelo ideológico. Son los instrumentos del ajuar los que nos ofrecen luz sobre el papel regio: los atributos servían para caracterizar a la realeza y, en algunos casos, se utilizarían de manera diferente según las circunstancias de cada reinado.

\section{BiBLIOGRAFÍA}

Abad Castro, C. 2001. "Espacios y capillas funerarias de carácter real”, en Isidro G. Bango Torviso (coord.), Maravillas de la España medieval. Tesoro sagrado y monarquía: 63-73. Valladolid: Junta de Castilla y León.

Alonso Álvarez, R. 2003. “De Carlomagno al Cid: la memoria de Fernando III en la capilla real de Sevilla", en Fernando III y su tiempo (1201-1252), VIII Congreso de Estudios Medievales: 469-488. Ávila: Fundación Sánchez-Albornoz.

Alonso Álvarez, R. 2007. "Los enterramientos de los reyes de León y Castilla hasta Sancho IV: Continuidad dinástica y memoria regia". E-Spania: Revue électronique d'études hispaniques médiévales, 3.

Amador de los Ríos, R. 1903. "Los túmulos reales de la capilla mayor en la catedral de Toledo". La España moderna, 177: 88-115.

Arco y García, F. 2012. "Heráldica eclesiástica". Emblemata: Revista aragonesa de emblemática, 18: 123-146.

Arco, R. 1954. Sepulcros de la Casa Real de Castilla. Madrid: Instituto Jerónimo Zurita. C.S.I.C.

Aries, P. 1983. El hombre ante la muerte. Madrid: Taurus.

Ballesteros Beretta, A. 1984. Alfonso $X$ el Sabio. Barcelona: El Albir.

\footnotetext{
108 González Arce, J.D. 1998: 127
} 
Bango Torviso, I.G. 1992. "El espacio para enterramientos privilegiados en la arquitectura medieval española". Anuario del Departamento de Historia y Teoría del Arte, 4: 93-132.

Bango Torviso, I.G. 2001. "De las insignias reales en la España medieval", en Imágenes y promotores en el arte medieval: miscelánea en homenaje a Joaquín Yarza Luaces: 59-66. Barcelona: Universidad Autónoma de Barcelona.

Bango Torviso, I.G. 2005. "La catedral de Toledo hacia 1400. Un centro creador en constante transformación", en La capilla de San Blas de la Catedral de Toledo: 21-32. Bilbao: Fundación Iberdrola.

Beltrán Torreira, F. 1990. "San Ildefonso de Toledo y el culto a la Virgen en la Iglesia hispano-visigoda: problemas históricos y doctrinales", en Devoción mariana y sociedad medieval actas del simposio. Ciudad Real del 22 al 24 de marzo, 1989: 439-454. Ciudad Real: Instituto de Estudios Manchegos.

Bizzarri, H.O. 2002. "Del texto a la imagen: representaciones iconográficas de la realeza en un manuscrito de los Castigos del rey don Sancho IV". Incipit, 22: 53-94.

Cabrera Sánchez, M. 2011. "La muerte de los miembros de la realeza hispánica medieval a través de los testimonios historiográficos". En la España medieval, 34: 97-132.

Cendón Fernández, M. 2007. "Arte y poder episcopal en la Castilla de los Trastámara". E-Spania: Revue électronique d'études hispaniques médiévales, 3.

Chamberlin, C.L. 2000. "Unless the pen writes as it should: the proto-cult of Saint Fernando III in Seville in the thirteenth and fourteenth centuries", en Manuel González Jiménez (coord.), Sevilla 1248: Congreso Internacional Conmemorativo del 750 Aniversario de la Conquista de la Ciudad de Sevilla por Fernando III, Rey de Castilla y León, Sevilla, Real Alcázar, 23-27 de noviembre de 1998: 389-418. Madrid: Centro de Estudios Ramón Areces.

Cómez Ramos, R. 1979. Las empresas artísticas de Alfonso X el Sabio. Sevilla: Diputación de Sevilla.

Dectot, X. 2009. Les tombeaux des familles royales de la Péninsule Ibérique au Moyen Âge. Turnhout: Brepols.

Delgado Roig, J. 1948. "Examen médico legal de unos restos históricos". Archivo hispalense: Revista histórica, literaria y artística, 9/27-32: 135-153.

Domínguez Rodríguez, A. 2010-2011. "Retratos de Alfonso $X$ en el Libro de los Juegos de Ajedrez, Dados y Tablas". Alcanate: Revista de estudios Alfonsíes, 7 (Ejemplar dedicado a: VII Semana de Estudios Alfonsíes): 147-162.

Don Juan Manuel; Alvar C. y Finci S. (ed.) 2007. Libro de las Armas, en Don Juan Manuel. Obras completas: 992997. Madrid: Biblioteca Castro, Fundación José Antonio de Castro.

Estepa Díez, C. 2010. "Naturaleza y poder real en Castilla", en J.A. Jara Fuente, G. Martin, I. Alfonso (coords.), Construir la identidad en la Edad Media: poder y memoria en la Castilla de los siglos VII a XV: 163-182. Cuenca: Ediciones de la Universidad de Castilla-La Mancha.
Fernández Collado, A. 1999. "El retablo de la Capilla Mayor de la Catedral de Toledo". XX Siglos, Vol. 10, 42: 74-81.

Fernández Fernández, L. 2010. “"Muy noble, et mucho alto et mucho honrado". La construcción de la imagen de Fernando III", en Carlos de Ayala Martínez, Martín Federico Ríos Saloma (coords.), Fernando III: tiempo de cruzada: 137164. Madrid-México: Universidad Nacional Autónoma de México, Instituto de Investigaciones Históricas, Sílex.

Flori, J. 1983. L'Ideologie du glaive. Préhistoire de la chevalerie. Ginebra: Droz.

Fournès, G. 2004. "L'idéalité royale en Castille au XIII" siècle: des Sept Parties aux Castigos del rey don Sancho IV". Cahiers de linguistique et de civilisation hispaniques médiévales, 27: 293-310.

Gaibrois de Ballesteros, M. 1922-1928. Historia del reinado de Sancho IV de Castilla. Madrid: Tipografía de la Revista de Archivos - Bibliotecas y Museos.

García Rey, V. 1922. "La capilla del rey don Sancho el Bravo y los cenotafios reales en la catedral de Toledo". Boletín de la Real Academia de Bellas Artes y Ciencias Históricas de Toledo, 3: 129-148.

Gómez Redondo, F. 1998. Historia de la prosa medieval castellana I: La creación del discurso prosístico: el entramado cortesano. Madrid: Ediciones Cátedra.

Gómez-Moreno, M. 1948. "Preseas reales sevillanas". Archivo hispalense: Revista histórica, literaria y artística, 9/27-32: 191-204.

González Arce, J.D. 1993. "El color como atributo simbólico del poder (Castilla en la baja Edad Media)". Cuadernos de arte e iconografía, 6, 11: 103-108.

González Arce, J.D. 1998. Apariencia y poder: la legislación suntuaria castellana en los siglos XIII y XV. Jaén: Universidad de Jaén.

González Jiménez, M. 2004. Alfonso X, el Sabio. Barcelona: Ariel.

González Jiménez, M. (ed.) 1999. Crónica de Alfonso X. Según el Ms. II/2777 de la Biblioteca del Palacio Real (Madrid). Edición, transcripción y notas. Murcia: Real Academia Alfonso X el Sabio.

González Mínguez, C. 2012. Poder real y poder nobiliar en la Corona de Castilla (1252-1369). Bilbao: Universidad del País Vasco.

Gutiérrez Baños, F. 1998. Las empresas artísticas de Sancho IV El Bravo. Burgos: Junta de Castilla y León Consejería de Educación y Cultura.

Haro Cortés, M. 1996. La imagen del poder real a través de los compendios de castigos castellanos del siglo XIII. Londres: Departament Studies - Queen Mary and Westfield College.

Haro Cortés, M. 2012. "Proyecto iconográfico del códice miniado de los "Castigos de Sancho IV" (BNE, Ms. 3995)", en Antonia Martínez Pérez y Ana Luisa Baquero Escudero (coords.), Estudios de literatura medieval: 25 años de la Asociación Hispánica de Literatura Medieval: 83-104. Murcia: Servicio publicaciones Universidad de Murcia. 
Heim, D. 2003. "Entre Mendoza y Cisneros: la gestación del retablo mayor de la catedral de Toledo". Anales Toledanos, 39: 103-116.

Jiménez Martín, A. 1997. Cartografía de la Montaña Hueca. Notas sobre los planos históricos de la Catedral de Sevilla. Sevilla: Cabildo Metropolitano de la Catedral.

Jiménez Martín, A. 2006. "Las fechas de las formas", en Alfonso Jiménez Martín (coord.), La catedral de Sevilla. Fundación y fábrica de la obra nueva: 15-114. Sevilla: Universidad de Sevilla.

Laguna Paúl, M.T. 2001. "La capilla de los reyes de la primitiva Catedral de Santa María de Sevilla y las relaciones de la Corona castellana con el cabildo hispalense en su etapa fundacional (1248-1285)", en Isidro G. Bango Torviso (coord.), Maravillas de la España medieval: Tesoro sagrado y monarquía, vol. I: 235-251. Valladolid: ed. Junta de Castilla y León.

Laguna Paúl, M.T. 2009a. "El Imperio y la Corona de Castilla: la visita a la capilla de los Reyes de Sevilla en 1500", en María C. Cosmen, María Victoria Herráez Ortega, María Pellón Gómez-Calcerrada (coords.), El intercambio artístico entre los reinos hispanos y las cortes europeas en la Baja Edad Media: 217-238. León: Universidad de León.

Laguna Paúl, M.T. 2009b. "“Si el nuestro cuerpo fuere enterrado en Sevilla". Alfonso X y la capilla de los reyes", en Alfonso X el Sabio [exposición] Sala San Esteban, Murcia, 27 octubre 2009-31 enero 2010: 116-129. Murcia: Comunidad Autónoma Región de Murcia, Ayuntamiento de Murcia y Caja de Ahorros del Mediterráneo.

Laguna Paúl, M.T. 2013a. "Devociones reales e imagen pública en Sevilla". Anales de historia del arte, № Extra 2: 127-157.

Laguna Paúl, M.T. 2013b. “Mobiliario medieval de la capilla de los Reyes de la catedral de Sevilla. Aportaciones a los "ornamenta ecclesiae" de su etapa fundacional". Laboratorio de Arte: Revista del Departamento de Historia del Arte, 25, 1: 53-77.

Linehan, P. 1986. "Pseudo-historia y pseudo-liturgia en la obra Alfonsina”, en España y Europa: un pasado jurídico común: 259-274. Murcia: Universidad. Instituto de Derecho Común.

Linehan, P. 2012. Historia e historiadores de la España Medieval. Salamanca: Universidad de Salamanca.

Loaysa, Jofré de; Antonio García Martínez (ed.) 1982. Crónica de los Reyes de Castilla, Fernando III, Alfonso X, Sancho IV y Fernando IV (1248-1305). Murcia: Academia Alfonso X el Sabio; Edición, traducción, introducción y notas por Antonio García Martínez.

Martínez de Aguirre, J. 1995. "La primera escultura funeraria gótica en Sevilla: la Capilla Real y el Sepulcro de Guzmán el Bueno (1248-1320)". Archivo español de arte, Tomo 68, 270: 111-130.

Menéndez Pidal, F. 2011. Heráldica de la Casa Real de León y Castilla (siglos XII-XVI). Navarra: Ediciones Hidalguía.

Merchán Cornello, M.M. 1958. Historia de la Capilla Real de Sevilla, Tesis de licenciatura dirigida por el profesor
Julio González y defendida el 28-02-1958 en la Facultad de Filosofía y Letras de la Universidad de Sevilla. Apéndice documental № 4: 294-303.

Mitre Fernández, E. 1988. "La muerte del rey. La historiografía hispánica (1200-1348) y la muerte entre las élites". En la España medieval, 11: 167-183.

Mitre Fernández, E. 1991. "Muerte y memoria del Rey en la Castilla bajomedieval", en La Idea y el sentimiento de la muerte en la historia y en el arte de la Edad Media: 17-26. Santiago de Compostela: Universidad de Santiago de Compostela.

Mitre Fernández, E. 2004. Fantasmas de la sociedad medieval: enfermedad, peste, muerte. Valladolid: Universidad de Valladolid.

Monreal Casamayor, M. 2006. "De Sermone Heráldico II: El Águila". Emblemata: Revista aragonesa de emblemática, 12: 289-334.

Monterde García, J. 2007. “El sueño imperial Alfonsí en "Las Siete Partidas"”. Murgetana, 117: 9-18.

Morales Cano, S. 2011. "La escultura funeraria gótica en la provincia de Toledo". Anales de historia del arte, 1 (Ejemplar dedicado a: Saberes artísticos bajo signo y designios del "Urbinate"): 353-364.

Moreta Velayos, S. 1996. "Notas sobre el franciscanismo y dominicanismo de Sancho IV y María de Molina", en José Ignacio de la Iglesia Duarte, Javier García Turza, José Ángel García de Cortázar y Ruiz de Aguirre (coords.), VI Semana de Estudios Medievales: Nájera, 31 de julio al 4 de agosto de 1995: 171-184. Nájera: Instituto de Estudios Riojanos.

Morgado, A. 1587. Historia de Sevilla, en la qual se contienen sus antiguëdades, grandezas, y cosas memorables en ella acontecidas, desde su fundación hasta nuestros tiempos. Libro IV. Sevilla: Imprenta de A. Pescioni y J. de Leon.

Muñoz Fernández, A. 2009. "Llanto, palabras y gestos. La muerte y el duelo en el mundo medieval hispánico (morfología ritual, agencias culturales y controversias)". Cuadernos de historia de España, 83: 107-140.

Nieto Soria, J.M. 1986. "Imágenes religiosas del rey y del poder real en la Castilla del siglo XIII". En la España Medieval, 5: 710-729.

Nieto Soria, J.M. 1987. "La monarquía Bajomedieval castellana ¿Una realeza sagrada?”, en Homenaje al profesor Juan Torres Fontes, vol. II: 1225-1237. Murcia: Universidad de Murcia.

Nieto Soria, J.M. 1988a. Fundamentos ideológicos del poder real en Castilla (siglos XIII-XVI). Madrid: Eudema.

Nieto Soria, J.M. 1988b. Iglesia y poder real en Castilla: el episcopado, 1250-1350. Madrid: Universidad Complutense de Madrid.

Nieto Soria, J.M. 1989. "Los fundamentos mítico-legendarios del poder regio en la Castilla bajomedieval", en Jean-Pierre Etienvre (ed.), La leyenda. Antropología, historia, literatura: actas del coloquio celebrado en la Casa de Velázquez, Madrid 10 y 11-XI-1986: 56-68. Madrid: Casa de Velázquez y Universidad Complutense de Madrid. 
Nieto Soria, J.M. 1992. "Lo divino como estrategia de poder en Castilla (siglos XIII al XV)", en Sección cronológica $=$ Section chronologique $=$ Chronological Section, vol. II: 669-674. Madrid: Comité Internacional des Sciencies Historiques.

Nieto Soria, J.M. 1993. Ceremonias de la realeza: propaganda y legitimación en la Castilla Trastámara. Madrid: Editorial Nerea.

Nieto Soria, J.M. 1994. Sancho IV, 1284-1295. Palencia: Diputación Provincial de Palencia - La Olmeda.

Nieto Soria, J.M. 1997. “Origen divino, espíritu laico y poder real en la Castilla del siglo XIII". Anuario de Estudios Medievales, 27: 43-101.

Nieto Soria, J.M. 2000. "Religión y política en la Castilla bajomedieval: algunas perspectivas de análisis en torno al poder real". Cuadernos de historia de España, 76: 99-120.

Nieto Soria, J.M. 2001. "La coronación del rey: los símbolos y la naturaleza de su poder", en Miguel Rodríguez Llopis (coord.), Alfonso X y su época: el siglo del rey sabio: 127152. Barcelona: Carroggio.

Nieto Soria, J.M. 2007. "El poder real como representación en la monarquía castellano-leonesa del siglo xIII". Res Publica, 17: 81-104.

Nogales Rincón, D. 2009. La representación religiosa de la monarquía castellano-leonesa: la Capilla Real (12521504), Tesis doctoral bajo la dirección de José Manuel Nieto Soria, Universidad Complutense de Madrid, 2009.

Nogales Rincón, D. 2014. “Rey, sepulcro y catedral. Patrones ideológicos y creación artística en torno al panteón regio en la corona de Castilla (1230-1516)", en María Dolores Teijeira Pablos, María Victoria Herráez Ortega y María C. Cosmen (coords.), Reyes y prelados: la creación artística en los reinos de León y Castilla (1050-1500): 257282. Madrid: Sílex Ediciones.

Núñez Rodríguez, M. 1985. "Iconografía de humildad: el yacente de Sancho IV". Boletín del Museo Arqueológico Nacional, 3/2: 170-175.

Núñez Rodríguez, M. 1988. "La indumentaria como símbolo en la iconografía funeraria", en Manuel Núñez Rodríguez, Ermelindo Portela Silva (coords.), La idea y el sentimiento de la muerte en la historia y en el arte de la Edad Media: Ciclo de conferencias celebrado del 1 al 5 de diciembre de 1986: 9-19. Santiago de Compostela: Universidade de Santiago de Compostela.

O'Callaghan, J.F. 1998. Alfonso $X$ and the Cantigas de Santa Maria: a poetic biography. Leiden: Brill.

Ortiz de Zúñiga, D. 1796. Anales eclesiásticos y seculares de la muy noble y muy leal ciudad de Sevilla metrópoli de Andalucía, tomo IV y V. Madrid: Imprenta Real.

Palacios Martín, B. 1976. "Los símbolos de la soberanía en la Edad Media española. El simbolismo de la espada", en VII Centenario del infante don Fernando de la Cerda: 273296. Ciudad Real: Instituto de Estudios Manchegos.

Palacios Martín, B. 1988. "Investidura de armas de los reyes españoles en los siglos XII-XIII", en Bonifacio Palacios
Martín (ed.), Las Armas en la historia (siglos x al XIV): Actas del Primer Simposio nacional sobre las Armas en la Historia, marzo 1983: 153-192. Jaraíz de la Vera: Gladius.

Panofsky, E. 1979. El significado en las artes visuales. Madrid: Alianza Editorial.

Pérez Monzón, O. 2012. “Imágenes sagradas. Imágenes sacralizadas. Antropología y devoción en la Baja Edad Media". Hispania sacra, 64/130: 449-495.

Presilla, M.E. 1987. "The Image of Death and Political Ideology in the Cantigas de Santa María", en Studies on the "Cantigas de Santa María". Art, Music, and Poetry: 403-457. Madison: Universidad de Nueva York.

Relanzón García-Criado, J.M. 1959. “La corona y la espada de Sancho IV de Castilla". Boletín de la Real Academia de Bellas Artes y Ciencias Históricas de Toledo, 69-70-71: 24-32.

Rivera Recio, J.F. 1985. "Los restos de Sancho IV en la catedral de Toledo: crónica retrospectiva". Boletín de la Real Academia de Bellas Artes y Ciencias Históricas de Toledo, 16/año LXIX: 127-138.

Rodríguez López, A. 1991. "Fernando III el Santo (12171252): evolución historiográfica, canonización y utilización política", en Miscel.lania en homenatge al P. Agustí Altisent: 573-588. Tarragona: Diputación de Tarragona.

Rossel, C. 1875-1878. Crónicas de los reyes de Castilla, desde Don Alfonso el Sabio hasta los católicos Don Fernando y Doña Isabel: 3 vols. Madrid: M. Rivadeneyra.

Roumier, J. 2013. "Un mundo de colores. Fuerza y significado del cromatismo en los relatos de viajes hispánicos a finales de la edad media". Epos: Revista de filología, 29: 117-129.

Rucquoi, A. 1995. “De los reyes que no son taumaturgos. Los fundamentos de la realeza en España". Temas medievales, 5: 163-186 y reeditado en 2006. Rex, Sapientia, Nobilitas. Estudios sobre la Península Ibérica Medieval: 9-45. Granada: Universidad de Granada.

Ruiz Souza, J.C. 1998. "Las capillas reales catedralicias bajomedievales de Sevilla, Toledo y Córdoba", en II Jornadas técnicas de conservadores de las catedrales. Las catedrales de España. Alcalá de Henares, 6-7 Noviembre de 1998, Alcalá de Henares: Universidad de Alcalá de Henares.

Ruiz Souza, J.C. 2006. “Capillas Reales funerarias catedralicias de Castilla y León: nuevas hipótesis interpretativas de catedrales de Sevilla, Córdoba y Toledo". Anuario del Departamento de Historia y Teoría del Arte, 18: 9-30.

Ruiz, T.F. 1984. "Une royauté sans sacré: la monarchie castillane du bas Moyen Âge". Annales. Économies, Sociétés, Civilisations, 39: 429-453.

Ruiz, T.F. 1987. “L'image du pouvoir à travers les sceaux de la monarchie castillane", en Adeline Rucquoi (dir.), Génesis medieval del estado moderno: Castilla y Navarra (1250-1370): 217-227. Valladolid: Ámbito.

Sánchez Ameijeiras, R. 2002. "La fortuna sevillana del códice florentino de las Cantigas: tumbas, textos e imágenes". Quintana: revista de estudios do Departamento de Historia da Arte, 1: 257-273. 
Sanz Serrano, M.J. 1998. "Imagen del antiguo tabernáculo de plata, de la Capilla Real de Sevilla, a través de dos sellos medievales", Laboratorio de Arte: Revista del Departamento de Historia del Arte, 11: 51-68.

Sanz Serrano, M.J. 2000. "Ajuares funerarios de Fernando III, Beatriz de Suabia y Alfonso X", en Manuel González Jiménez (coord.), Sevilla 1248: Congreso Internacional Conmemorativo del 750 Aniversario de la Conquista de la Ciudad de Sevilla por Fernando III, Rey de Castilla y León, Sevilla, Real Alcázar, 23-27 de noviembre de 1998: 419-450. Madrid: Centro de Estudios Ramón Areces.

Schramm, P.E. 1960. Las insignias de la realeza en la Edad Media española. Madrid: Instituto de Estudios Políticos.

Serrano Coll, M. 2011. "Los signos del poder: regalías como complemento a los emblemas de uso inmediato". Emblemata: Revista aragonesa de emblemática, 17: 129-154.

Solazzo, C; Dyerb, J.M.; Clerensb, S.; Plowmanb, J.; Peacocke, E.E.; Collins, M.J. 2013. "Proteomic evaluation of the biodegradation of wool fabrics in experimental burials". International Biodeterioration \& Biodegradation, 80: 48-59.

"Testamento" de Sancho IV el Bravo dado el 14 de febrero de 1285 , Soria. Pergamino escrito en castellano con letra minúscula cursiva. $600 \times 635$ mm. Archivo Histórico Nacional de Madrid, Sección clero, carpeta 3022, no 5 bis. Publicado en Escudero de la Peña, J.M. 1872. "Privilegio miniado e historiado del rey don Sancho IV". M.E.A., tomo I: 98.

Torija Rodríguez, E. 2014. "Las capillas funerarias reales de la catedral de Toledo. Elementos humanos y legitimadores", en María Dolores Teijeira Pablos, María Victoria Herráez Ortega y María C. Cosmen (coords.), Reyes y prelados: la creación artística en los reinos de León y Castilla (1050-1500): 283-295. Madrid: Sílex Ediciones.

Torres Fontes, J. 2002. "El corazón de Alfonso X el Sabio en Murcia”. Murgetana, 106: 9-15.

Valdeón Baruque, J. 2003. Alfonso X el Sabio: la forja de la España moderna. Madrid: Temas de hoy. 